CONSERVACÃO

E RESTAURAÇÃO 


\section{Notas sobre a Carta de Veneza}

\section{Beatriz Mugayar Kühl'}

RESUMO: Este artigo propõe uma leitura crítica da Carta de Veneza, documento-base do Icomos, fruto de congresso realizado em 1964. No Brasil, a Carta é citada com muita frequência, mas não entendida na mesma medida. As chamadas cartas patrimoniais são documentos - em especial aquelas derivadas de organismos internacionais - cujo caráter é indicativo ou, no máximo, prescritivo. Constituem base deontológica para as várias profissões envolvidas na preservação, mas não são receituário de simples aplicação. Para elaborar uma leitura fundamentada do documento, suas formulações devem ser entendidas em relação aos postulados teóricos da época em que foi produzida e aos desdobramentos do campo. Aqui, abordam-se esses temas, associando-os a comentários e esclarecimentos a respeito dos artigos da Carta, mencionando a origem de determinadas ideias, a forma como a Carta se aproxima ou difere de documentos anteriores, e as bases teóricas de determinadas proposições ali contidas. Esse processo de análise crítica fundamentada do documento é necessário para que as indicações ali contidas possam ser interpretadas de modo mais pleno, de modo a poder utilizá-las, na prática, nos dias de hoje.

PalaVRAS-ChAVE: Carta de Veneza. Conservação. Restauração. Bens Culturais. Monumentos Históricos. Patrimônio Arquitetônico.

ABSTRACT: This paper presents a critical reading of the Venice Charter, an Icomos key document, fruit of a conference held in 1964. The Charter is often quoted in Brazil but is not always properly understood. The conservation and restoration charters - especially those produced by international institutions - are documents that have an indicatory or, at the most, prescriptive character. They constitute the deontological foundation of many professionals involved in preservation, but they are not recipes for immediate use. In order to elaborate a well-founded reading of the document, its ideas must be understood in connection to the theoretical postulates of the time they were engendered and to the developments of the field. Thus this paper will examine these subjects, commenting and enlightening the Charter's articles and pointing out the origins of specific ideas. It also discusses how the Charter relates to previous documents and their theoretical foundations. This approach, based in a critical analysis, is necessary in order to reach a fuller interpretation of the Charter's indications so that they can be used in the present. KEY WORDS: Venice Charter. Conservation. Restoration. Cultural Heritage. Historic Monuments. Architectural Heritage.
1. Docente da Faculdade de Arquitetura e Urbanismo da Universidade de São Paulo. E-mail: <bmk@usp.br>. 
2. Sigla de International Council on Monuments and Sites (Conselho Internacional de Monumentos e Sítios).

3. A palavra preservação, no Brasil, possui um sentido lato e pode abarcar uma grande variedade de ações como inventários, registros, leis de tombamento, educação patrimonial e intervenções nos bens, para que sejam transmitidos da melhor maneira possível ao futuro. As intervenções em si assumem denominações variadas, podendo, como explicitado na Carta de Veneza, ser caracterizadas como manutenção, conservação e restauro, com graus crescentes de ingerência sobre o bem. Ou, por exemplo, serem sintetizadas na palavra restauro, como proposto por Cesare Brandi. Existem ainda outras linhas, com raízes no pensamento de John Ruskin, que diferenciam conservação e restauro, não como parte de um mesmo processo (com graus distintos de invasividade), mas como ações de natureza diversa, tema a ser retomado adiante.

No trato de bens culturais, atualmente, são feitas menções, cada vez mais frequentes, às chamadas Cartas patrimoniais e, entre elas, a Carta de Veneza, fruto do II Congresso Internacional de Arquitetos e de Técnicos de Monumentos Históricos, realizado em Veneza de 25 a 31 de maio de 1964. Essa Carta permanece como documento-base do comos $^{2}$, criado em 1965 e acolhido pela Unesco como órgão consultor e de colaboração.

Analisar esses documentos de maneira fundamentada, para que se tenha um entendimento mais pleno de suas formulações, é atividade essencial para quem trabalha com preservação ${ }^{3}$, sobretudo por serem textos concisos, que têm, em geral, caráter indicativo e não constituem um receituário a ser aplicado diretamente na prática. As cartas patrimoniais têm dado origem, recentemente, a interpretações apressadas - não por acaso num período de aceleração do tempo, em que até mesmo parte da produção acadêmica é marcada por uma tendência "produtivista", incorrendo, por conseguinte, em "redutivismo" -, e muitas vezes equivocadas e superficiais. A Carta de Veneza, por permanecer um documento basilar para a preservação de obras e conjuntos arquitetônicos, tem sofrido particularmente dessa falta de reflexão aprofundada. $\bigcirc$ documento é muito debatido, em especial em efemérides (os trinta anos, os quarenta anos da Carta, que deram origem a eventos científicos); parece importante, no entanto, retomar a discussão neste momento, sem relação com uma data em particular, para expor temas relevantes, que podem oferecer instrumentos significativos para enfrentar questões atuais relacionadas à tutela do patrimônio. Esse exercício é fundamental no caso brasileiro, pois as motivações e implicações daquilo que está exposto na Carta não são discutidas maneira aprofundada no país, apesar das numerosas citações que são feitas do documento.

Nos dias de hoje, para interpretar as indicações contidas na Carta, de modo a poder utilizá-las na prática, impõe-se uma análise crítica fundamentada do documento. $\bigcirc$ intuito, aqui, é oferecer algumas contribuições nesse sentido. Para tanto, são abordados três temas, relacionados entre si:

- o papel das cartas patrimoniais e seu caráter - em especial aquelas derivadas de organismos internacionais - indicativo ou, no máximo, prescritivo; são documentos que se colocam como base deontológica para as várias profissões envolvidas na preservação, mas não constituem receituário de simples aplicação;

- as formulações da Carta de Veneza em relação aos postulados teóricos da época em que foi produzida e aos desdobramentos do campo, procurando também entender como suas propostas foram apreendidas, quais foram os questionamentos feitos ao documento e como ele foi interpretado, para poder elaborar uma leitura fundamentada e apontar aspectos que continuam atuais;

- comentários e esclarecimentos a respeito dos artigos da Carta, mencionando a origem de determinadas ideias, a forma como a 
Carta se aproxima ou difere de documentos anteriores, e as bases teóricas de determinadas proposições ali contidas, para que possam ser interpretadas de modo mais pleno.
4. Cf. Giovanni Carbonara (1995, p. 68).

O papel das cartas patrimoniais nas organizações

internacionais de preservação

As cartas patrimoniais são fruto da discussão de um determinado momento. Antes de tudo, não têm a pretensão de ser um sistema teórico desenvolvido de maneira extensa e com absoluto rigor, nem de expor toda a fundamentação teórica do período. As cartas são documentos concisos e sintetizam os pontos a respeito dos quais foi possível obter consenso, oferecendo indicações de caráter geral. Seu caráter, portanto, é indicativo ou, no máximo, prescritivo. Obviamente, cartas internacionais, como a de Veneza, não podem ter caráter normativo, pois suas indicações devem ser reinterpretadas e aprofundadas para as diversas realidades culturais de cada país, e ser, ou não, absorvidas em suas propostas legislativas. As cartas internacionais, se devidamente reinterpretadas para as realidades locais, podem resultar em cartas nacionais, ou articularem-se a elas; podem, assim, ter papel importantíssimo na construção normativa relacionada à preservação dos bens culturais dos vários países.

As cartas em geral, e a Carta de Veneza em particular, não são um receituário de utilização fácil, nem de relação mecânica de causa-efeito. Para poder utilizar suas proposições, que se equiparam a uma norma deontológica ${ }^{4}$, é necessário compreender sua natureza, as discussões que estão em sua base, os modos como suas indicações foram apreendidas e incorporadas na prática ao longo do tempo, e, assim, poder interpretar esses postulados de maneira fundamentada, com rigor metodológico.

Para tanto, é essencial conhecer o debate sobre o restauro no período em que a Carta de Veneza foi redigida, as razões que, naquela época, levaram a determinadas formulações, e a própria transformação, ao longo do tempo, do campo do restauro. As atas completas são fundamentais para ter uma ideia mais precisa das discussões ocorridas e da fundamentação teórica em debate. É necessário, ainda, ler o texto da Carta em sua inteireza, sempre; ou seja, interpretar seus artigos em relação ao conjunto das propostas contidas na Carta, e não retirar frases do contexto, desconsiderando o restante do documento, pois isso pode levar a conclusões paradoxais. É importante ter em mente, sempre, que a Carta contém uma série de princípios-guia, ou diretrizes, o que é algo muito diferente de regras e de um receituário para a sua aplicação. Esses princípios devem ser reinterpretados, para cada caso particular de aplicação, em função das colocações gerais contidas na Carta e da discussão que a fundamenta, e não de maneira literal, restritiva e redutora. Em itens seguintes deste artigo, oferecem-se algumas contribuições em relação a tais quesitos. 
5. Cf. Raymond Lemaire (1999, p. 43-44).

6. Sigla do órgão das Nações Unidas, United Nations Educational, Scientific and Cultural Organization (Organização Educacional, Científica e Cultural das Nações Unidas), estabelecido em 1945.

7. O Icom (International Council of Museums), fundado em 1946, mantém com a Unesco relações formais de colaboração e de papel consultivo. Atualmente tem também status consultivo no United Nations Economic and Social Council.

8. Cf. Raymond Lemaire (1999, p. 43-49).
É ainda de extrema importância compreender a Carta de Veneza dentro do quadro de criação e de consolidação de organizações internacionais voltadas para a cultura. No encontro de Veneza, em maio de 1964, além da Carta, foram emitidos outros doze documentos: o que se segue à Carta é a resolução referente à criação de organização não-governamental de monumentos e sítios, instituindo, para tal fim, um comitê organizador e um conselho executivo.

Desde as primeiras reuniões para organizar o Congresso de Veneza, em 1962 - segundo depoimentos de Raymond Lemaire ${ }^{5}$, que foi o relator da Carta e participou do processo de organização do lcomos -, já estava em pauta a proposta de criar uma organização para especialistas em monumentos. Essas propostas derivam de ideias anteriores, apresentadas em reuniões científicas, em especial a antecessora direta da reunião de Veneza - o primeiro Congresso Internacional de Arquitetos e Técnicos de Monumentos Históricos de Paris, em 1957. Em particular, Piero Gazzola, que esteve à frente do encontro de Veneza, tinha esse intento, pois sentia necessidade de uma instituição do gênero em seus trabalhos como especialista da Unesco․ Isso ficou ainda mais evidente durante os trabalhos para salvar os templos em Abu Simbel, no Egito, em que Gazzola constatou quão importante foi a colaboração com o lcom? .

Já o estatuto do Icomos foi baseado, em linhas gerais, no do Icom, instituição-irmã, da qual recebeu pleno apoio. Georges-Henri Rivière, um dos fundadores do Icom, foi grande incentivador da criação do Icomos, acreditando em seu papel relevante para assegurar um futuro para o patrimônio. No Congresso de Veneza, porém, houve uma cisão, pois alguns participantes que não haviam sido eleitos para a comissão organizadora da nova instituição pretenderam criar uma associação paralela, que seria voltada estritamente a arquitetos e engenheiros especializados em preservação. A ideia-base do Icomos era outra: a de um órgão que acolhesse todas as disciplinas e competências envolvidas na salvaguarda de bens culturais. Esse processo foi efetivado na assembleia-fundadora, de 1965, em Varsóvia, que elegeu Gazzola para a presidência; Lemaire, secretário-geral; e Maurice Berry, para a tesouraria. O Icomos foi bem acolhido por René Maheu, então Diretor-Geral da Unesco, e imediatamente admitido como organização de consultoria e colaboração, categoria $B$; dois anos mais tarde, passou à categoria A. No que se refere a aspectos operacionais, um apoio significativo veio do Ministro da Cultura da França, André Malraux, que ofereceu uma sede em Paris e apoio financeiro regular para $\mathrm{o}$ secretariado 8 .

A organização do congresso, que deu origem à Carta de Veneza, o próprio texto da Carta e, ainda, a criação do Icomos, fazem parte de um esforço cumulativo de várias nações (e também de seus serviços de preservação e de profissionais do campo) para estabelecer um sistema de cooperação internacional que auxiliasse na resolução das numerosíssimas questões envolvidas na preservação de bens culturais, de modo a enfrentá-las com rigor metodológico e coerência de critérios e de princípios. $\bigcirc$ antecessor mais direto da Carta de Veneza é a Carta de Atenas (de restauração), documento de 1931 - a não ser confundido com a Carta de Atenas (do Ciam), resultante de evento de 1933 -, resultado de reunião 
científica realizada em outubro daquele ano, organizada pelo Escritório Internacional de Museus da Sociedade das Nações9. Esse escritório é fruto de um reconhecimento, por parte da comunidade internacional, da relevância dos museus em atividades de cooperação internacional, também com o objetivo de um maior conhecimento recíproco que auxiliasse na manutenção da paz ${ }^{10}$. $\bigcirc$ Escritório $^{11}$ foi criado, em 1926, pela a Comissão Internacional de Cooperação Intelectual, da Sociedade das Nações, que era presidida por Henri Bergson, no quadro do Instituto Internacional de Cooperação Intelectual, através de proposta de Henri Focillon. Tinha por intuito desenvolver atividades comuns de pesquisa e publicações sobre museus e bens culturais. Em 1930, houve uma Conferência internacional de métodos científicos para o estudo e conservação de obras de arte, realizada em Roma, que propôs também a realização da Conferência de Atenas para a proteção dos monumentos, realizada no ano seguinte ${ }^{12}$. As recomendações de Atenas tiveram grande repercussão internacional e forneceram as bases para o documento de Veneza.

Icom, como mencionado, foi importante antecessor do lcomos, assim como da criação, pela Unesco, de uma organização intergovernamental, o lccrom $^{13}$, em 1956. Esses organismos internacionais contavam com a participação de numerosos profissionais altamente gabaritados, associados a organismos nacionais de preservação ou a serviços de conservação de importantes museus. No que se refere à criação do lccrom $^{14}$, cuja sede é em Roma, foi de grande importância a participação de Cesare Brandi, do Istituto Centrale per il Restauro $(\mid C R)^{15}$, de Roma, assim como a de Paul Coremans, diretor do Institut Royal du Patrimoine Artistique (Irpa), criado em 1948 em Bruxelas, e a de Germain Bazin, diretor do serviço de conservação do Louvre ${ }^{16}$.

$\bigcirc$ intuito de criar essas organizações internacionais com especialistas era, como insiste Brandi, "tirar o restauro das obras de arte mais importantes - que como tal pertencem à cultura universal - do arbítrio dos conservadores singulares"17 e tratar a questão de maneira fundamentada, vinculando-a ao pensamento crítico e às ciências. Era um contexto em que havia efetivo intercâmbio de ideias, não sem polêmicas ${ }^{18}$, e em que a divulgação de trabalhos e o debate sobre seus resultados ocorria de maneira intensa. As cartas relacionadas à preservação são um esforço de apresentar princípios sobre os quais havia consenso, de modo a embasar a conduta dos profissionais da área.

Cabe esclarecer, porém, uma confusão muito comum: falar das cartas patrimoniais como um conjunto homogêneo de documentos. Sem fazer a necessária distinção entre estes escritos, são colocadas num mesmo plano, por exemplo: a Carta de Atenas, de restauração, de 1931 ; a Declaração de Nara sobre a Autenticidade, de 1994, do lcomos; as Normas de Quito, da Organização dos Estados Americanos, de 1967; e a Carta e Declaração de Amsterdã, do Conselho da Europa, de 1975. Claro está que todos são de enorme interesse, mas estão longe de constituir um conjunto coerente, existindo, entre eles, numerosas contradições - justamente por serem elaborados em períodos distintos, por organismos e grupos diferentes, com finalidades diversas, tendo, portanto,
9. Nesse sentido, houve tentativas anteriores, como o Congresso Internacional sobre a Proteção de Obras de Arte e dos Monumentos (realizado na época da Exposição Universal em Paris, de 24 a 28 de junho de 1889). Foi evento importante para intercâmbio de dados e para verificar o estado em que estava a salvaguarda e as leis de proteção dos bens culturais nos vários países. Suscitou especial interesse a lei francesa, de 1887, que autorizava o Ministro da Educação a expropriar, em favor do Estado, caso estivesse em perigo um bem que pertencesse a um particular. Foi analisada ainda uma forma específica de vandalismo, a dos restauradores. Os participantes votaram a moção que, ao lidar com uma obra de arte (arquitetura, escultura ou pintura), o autor da intervenção deveria ser assistido por comissão multidisciplinar e elaborar relatório pormenorizado do estado da obra antes, durante e depois da restauração. Foram ainda abordados temas como a preservação do entorno dos monumentos públicos $\mathrm{e}$ a proteção dos monumentos em tempos de guerra. Recomendou-se a criação de convenção internacional e que, para cada país, uma comissão designasse edifícios a serem protegidos em caso de conflito. Esse congresso foi relevante para $o$ intercâmbio entre países e balão de ensaio para reuniões posteriores, como a de Atenas; ver Paul Saintenoy (1889).

10. Como bem explicita Rosalia Varoli-Piazza (2008, p 83-84). No entanto, contraditoriamente, ao ser criada, em 1920, a Sociedade das Nações não tinha entre suas atribuições a cooperação intelectual. Léon Bourgeois (membro da Academia de Ciências Morais e Políticas da França, prêmio Nobel da paz em 1920) propôs, em 1921, que a organização tivesse também a missão de colaborar no âmbito da cul- 
tura e da educação. Sua proposta não foi levada adiante, pois alguns países, então, consideravam a questão da educação como um problema de soberania nacional. Somente em 1922 foi criada a Comissão de Cooperação Intelectual, também para tratar de problemas de países que tiveram seu patrimônio cultural atingido pela Guerra. Henri Bergson foi designado para dirigir essa Comissão e, por sua iniciativa, fo criado em 1924, em Paris, o Instituto Internacional de Cooperação Intelectual; ver Jean Sirinelli (1995).

11. Assim chamado devido à denominação original em francês: Office International des Musées (OIM)

12. Cf. Rosalia Varoli-Piazza (2008, p. 84-85).

13. Cuja denominação atual é International Centre for the Study of the Preservation and Restoration of Cultural Property.

14. A origem, intuitos e organização dessas instituições e as várias inter-relações entre as personagens envolvidas, começam a ser tratadas de maneira mais aprofundada em pesquisas recentes, através da análise de seu acervo de documentos. Sobre a criação do Iccrom, além do texto de Rosalia Varoli-Piazza, ver a edição especial do ICCROM Newsletter, de outubro de 2009, dedicado à criação do órgão.

15. Criado em 1939, atual Istituto Superiore per la Conservazione ed il Restauro.

16. Pelo que informa Rosalia Varoli-Piazza (2008, p. 87-88), a escolha da sede do Iccrom em Roma foi relacionada à necessidade de articular a nova instituição com uma estrutura estatal já existente (que na Europa seria o ICR ou o Irpa), sendo que Roma seria mais bem vista pelos colegas franceses que tinham os postos mais intenções e repercussão bastante variadas -, que devem ser devidamente pesadas e evidenciadas.

Mesmo entre documentos de uma única instituição, há diferenças consideráveis, que devem ser ressaltadas para não gerar equívocos. Aproveitando que o tema deste artigo é uma carta do lcomos, é necessário relembrar que existem cartas que são adotadas pela Assembleia Geral da instituição e deveriam ser seguidas por todos os Comitês Nacionais e por todos os membros - individuais ou institucionais - do lcomos.

Uma carta, com seu caráter indicativo e prescritivo, difere de resoluções e declarações de simpósios do próprio lcomos, que têm por intuito apresentar o estado da arte de uma dada discussão e oferecer subsídios ao debate. Esse é o caso, por exemplo, do Documento de Nara sobre a Autenticidade, de 1994, que frequentemente é citado como Carta, mas não o é. E, muito menos, coloca-se como texto substitutivo à Carta de Veneza, devendo ser reiterado que o Documento de Nara reafirma os postulados de Veneza ${ }^{19}$. No Documento de Nara, são reconhecidas a diversidade cultural e a pluralidade de formas ao lidar com o passado; suas implicações para a preservação são tratadas mais adiante.

As Cartas adotadas pela Assembleia Geral tampouco são equiparáveis às Cartas produzidas pelos Comitês Nacionais do Icomos; são documentos de interesse, e veiculados pelo sítio do lcomos internacional (numa categoria distinta, porém), mas não são referendados pela Assembleia Geral, o que significa que sua validade é local. Por vezes, apesar de seu interesse, alguns documentos não são avalizados pela Assembleia Geral, pois contêm definições contraditórias às do documento-base da instituição, que continua sendo a Carta de Veneza.

Tomando como exemplo a Carta de Burra, do Icomos-Austrália, a definição de restauro ali contida é: "a restauração será o restabelecimento da substância de um bem em um estado anterior conhecido"20. Essa é uma visão sobre o restauro que prevaleceu até o século XIX ${ }^{21}$, tendo sido refutada, num documento de âmbito nacional, nas resoluções do IV Congresso de Engenheiros e Arquitetos italianos, de 1883 - que mostram a repercussão das propostas de Camillo Boito, adotadas pelo Ministério da Educação do país22 -, e, em âmbito austríaco, pelo menos desde as proposições de Alois Rieg| ${ }^{23}$, no início do século XX; e, ainda, no contexto internacional, desde a Carta de Atenas, de 1931, que teve ativa participação de Gustavo Giovannoni.

São posturas que amadurecem na segunda metade do século XIX e início do século XX, com ênfase no valor documental das obras, respeitando suas várias estratificações ao longo dos séculos, sua configuração, e as próprias marcas da passagem do tempo. Contrapunham-se às numerosíssimas experiências, efetuadas ao longo do século XIX, em que se buscava reconstituir o estado "original" da obra, muitas vezes idealizado, conduzindo a irreparáveis perdas e deformações - além de induzir o observador ao engano de confundir estratos de uma obra historicizada com algo feito recentemente. Essas ações levantaram muita polêmica já naquele período, não apenas por especialistas, mas por parte de comunidades que não mais se reconheciam naqueles monumentos transfigurados e "novos em folha". Note-se que a visão contida na Carta de Burra remete às 
discussões em âmbito cultural anglófono, em que determinadas palavras associam-se a conceitos e modos de operar que não são aqueles referendados por organismos internacionais ${ }^{24}$.

Ou seja, na visão de restauro, como enunciada a partir de finais dos oitocentos e reiterada na Carta de Veneza, não se "volta" a estado algum anterior; "vai-se" em direção a uma conformação renovada, que respeita as fases precedentes e as próprias marcas da passagem do tempo. Note-se também que, com base nas experiências do século XIX, reconstruções ao idêntico lou de uma fase anterior qualquer) não são ações admitidas no âmbito da preservação; no máximo, são feitas anastiloses ${ }^{25}$. $\bigcirc$ caráter de documento histórico dos bens culturais é enfatizado e, por isso, tais bens não são reproduzíveis e não devem ser desnaturados. Refazer um bem desaparecido equivale a falsificar um documento.

Uma objeção comum à Carta de Veneza, devida às suas várias décadas de existência, é considerá-la um documento "ultrapassado", que teria sido "substituído" por documentos posteriores do lcomos, como a "Carta" de Nara (que como visto, não é carta, é documento) e a Carta de Burra (que não é referendada pela Assembleia Geral). Além dos evidentes equívocos factuais, os documentos posteriores do lcomos não se colocam como substitutivos, mas como integrativos. Nenhuma outra carta foi feita ou aprovada para substituir a Carta de Veneza; não porque a instituição seja relapsa (basta seguir a numerosa produção científica e os debates sobre a Carta ${ }^{26}$ ), mas porque seus princípios são, ainda, considerados fundamentalmente válidos para o trato de edifícios de interesse para a preservação, continuando a ser o documento-base da instituição ${ }^{27}$; nem por isso está isenta de questionamentos fundamentados, que são retomados adiante.

Por ser a Carta de Veneza centrada em monumentos e sítios históricos, e levando em conta o alargamento daquilo que passou a ser considerado bem cultural la definição que consta da Carta é abrangente, mas o campo ampliou-se ainda mais desde então) - abarcando tipos cada vez mais variados de bens, relacionados a um passado cada vez mais próximo -, o que tem sido feito, ao longo dos anos, é produzir documentos integrativos e de aprofundamento, reinterpretando (de maneira fundamentada), para esse contexto mais amplo, os princípios da Carta de Veneza e tratando de temas não contemplados diretamente por ela. Desse modo, foram elaboradas as seguintes cartas, adotadas pela Assembleia Geral do lcomos: Carta dos jardins históricos (Carta de Florença), 1981 ; Carta internacional para a salvaguarda de cidades históricas /Carta de Washington), 1987; Carta internacional do patrimônio arqueológico, 1990; Carta internacional sobre a proteção e gestão do patrimônio cultural subaquático, 1996; Carta internacional do turismo cultural, 1999; Princípios a seguir para a conservação de estruturas históricas de madeira, 1999; Carta do patrimônio construído vernacular, 1999; Carta de princípios para a análise, conservação e restauração de estruturas do patrimônio arquitetônico, 2003; Carta para a preservação e a conservação-restauração de pinturas murais, 2003; Carta dos itinerários culturais, 2008; Carta para a interpretação e a apresentação de sítios culturais patrimoniais, $2008^{28}$. importantes no Icom - por causa da rivalidade com Bruxelas. Brandi queria que o diretor fosse alguém com sólida formação humanística, mas a escolha recaiu em $\mathrm{Ha}$ rold Plenderleith, químico, diretor do Laboratório de Pesquisas do British Museum. Foi Brandi que insistiu, então, que Paul Philippot, que conhecia desde 1949 quando este último veio a Roma realizar pesquisa sobre o ICR, assumisse o posto de vice-diretor, para contrabalançar a tendência cientificista do diretor. Philippot, por sua vez, dirigiria a instituição entre 1971 e 1977. Apesar dessa atribulação inicial, a colaboração entre Plenderleith e Brandi foi muito intensa $\mathrm{e}$ frutuosa. No que se refere ao serviço de conservação do Louvre e à estreita colaboração com o ICR ver Segolène Bergeon Langle (2008)

17. Cesare Brandi, apud Rosalia Varoli-Piazza (2008, p. 85).

18. A mais conhecida delas é a "cleaning controversy" (controvérsia das limpezas), iniciada em 1947 - quando a National Gallery de Londres organizou uma exposição de quadros recentemente limpos (An Exhibition of Cleaned Pictures) - e estendeu-se até o início dos anos 1960. Sobre essa questão, cf. Cesare Brandi (2004, p.153-208); ver também Alessandro Conti (1988).

19. "O Documento de Nara sobre a Autenticidade é concebido no espírito da Carta de Veneza, 1964, baseando-se nele e ampliando-o de modo a responder ao alargamento das preocupações e interesses daquilo que é considerado patrimônio cultural em nosso mundo contemporâneo." Cf. Unesco (1995, p. xxI).

20. A tradução da Carta de Burra, versão de 1980, está disponível no sítio do Iphan.

21. Sobre as transformações no campo, e suas razões, ao 
longo dos séculos, existe uma abundante literatura. Como exemplo de textos fundamentados, que remetem a uma ampla bibliografia, ver Giovanni Carbonara (1997); Françoise Choay (2001); Jukka Ilmari Jokilehto (1999).

22. Ver as Atas do Congresso degli Ingegneri ed Architetti Italiani, 4. (1884).

23. Para análise pormenorizada do papel de Riegl para a tutela dos monumentos através da formulação de variados autores, ver Sandro Scarrocchia (1995). No livro também estão presentes textos de Riegl - O culto moderno dos monumentos; Projeto de organização legislativa para a conservação de monumentos na Áustria; Disposições para a aplicação da lei - que fundamentam sua visão sobre o tema e sua proposta normativa.

24. No que respeita ao ambiente anglófono, vale mencionar que operam de modo coerente com suas próprias definições. Mais grave é o que ocorre em muitos países, entre eles o Brasil, que, do ponto de vista teórico, alinha-se às resoluções do Icomos, por exemplo, mas são muito comuns, na prática, as reconstruções ou voltas a estados anteriores dos bens.

25. Até mesmo na Carta de Burra, em que se admitem reconstruções, recomenda-se que essa ação seja feita com materiais diferentes, de modo a ser distinguível: "A reconstrução será o restabelecimento, com o máximo de exatidão, de um estado anterior conhecido; ela se distingue pela introdução na substância existente de materiais diferentes, sejam novos ou antigos. A reconstrução não deve ser confundida nem com a recriação, nem com a reconstituição hipotética, ambas excluídas do domínio regulamentado pelas presentes orientações".
Outra oposição à Carta de Veneza é que ela seria um documento eurocêntrico le por isso alguns creem erroneamente que tenha sido substituída pelo Documento de Nara). No congresso realizado em Veneza, havia representantes dos mais variados países (inclusive Brasil), de todos os continentes ${ }^{29}$, apesar de a maioria dos participantes ser de países ocidentais, e de instituições internacionais - Unesco, Conselho da Europa, Iccrom (representado pelo seu diretor Plenderleith e pelo seu vice-diretor, Philippot), Icom (representado por Hughes de Varine-Bohan). Claro está que havia ideias conflitantes ${ }^{30}$ e os debates foram numerosos, como é natural e saudável que ocorra ${ }^{31}$. O texto da Carta é uma síntese propositiva, baseada nos pontos sobre os quais houve acordo. É fato que o documento é devedor do debate europeu, em especial italiano, sobre o tema. Basta ver os enunciados contidos na proposta de carta, já pronta previamente, apresentada ao Congresso por Gazzola e Pane ${ }^{32}$, pautada nos princípios do chamado restauro crítico e numa releitura da Carta de Atenas de 1931 e da Carta italiana de restauro de 1931-1932, com as revisões de 1938, que, em determinados pontos, avança até mais do que a Carta de Veneza. Há de se enfatizar ainda o papel de dois belgas: Philippot; e Lemaire (membro do conselho do Istituto Internazionale dei Castelli, do qual Gazzola era Presidente do conselho científico), que foi relator da carta e relator-geral do Congresso. Ambos tinham estreitas afinidades com o expressivo debate sobre restauro que se desenrolava na Itália desde os anos 1940. No final, predominaram as propostas ligadas a um grupo de intelectuais que tinha relação direta com as ideias debatidas na Itália naquele período. Ser devedor das discussões europeias, não significa, porém, ser eurocêntrico. $\bigcirc$ que ocorre, e esse é um ponto que será examinado adiante, é a Carta de Veneza ser um documento voltado aos "monumentos históricos".

\section{Carta de Veneza e suas bases teóricas: formas de apreensão e atualidade}

Em relação ao tema, como mencionado acima, as propostas da Carta de Veneza são pautadas na visão conhecida como "restauro crítico".

$\bigcirc$ restauro crítico elabora uma releitura das propostas filiadas ao "restauro filológico", de Boito e Giovannoni, consolidadas nas cartas dos anos 1930. No restauro filológico, era dada grande atenção aos aspectos documentais das obras e às marcas de sua passagem ao longo do tempo, respeitando as várias fases; o intuito não era, de modo algum, voltar a um suposto estado original. Se houvesse necessidade de inserir novos elementos, deveriam ser diferenciados da obra como estratificada, para não induzir o observador ao engano de confundir a intervenção com a obra (em alguma de suas etapas). Daí a denominação "restauro filológico", pois a ação pode assemelhar-se a edições críticas de textos, em que, ao tratarem-se as lacunas do documento, quaisquer interpolações e interpretações são feitas através de elementos diferenciados: tipo e cor da letra, notas à margem do escrito. 
restauro filológico, porém, mostrou certos limites, que ficaram evidentes com as devastações geradas pela Segunda Guerra Mundial. Mostrou-se insuficiente considerarem-se tão-só as questões documentais da obra, não trabalhando, conjuntamente, com meios conceituais mais elaborados para lidar com seus aspectos de conformação e figurativos, assim como tratar lacunas (pictóricas, escultóricas, arquitetônicas, urbanas) através de "neutros". Desse modo o restauro crítico, ao mesmo tempo em que acolhe os princípios fundamentais do restauro filológico - de respeito pelas várias estratificações do bem e de diferenciar a ação contemporânea -, também os associa ao tratamento da dimensão formal das obras, trazendo para a discussão teorias estéticas e questões relacionadas à percepção próprias da primeira metade do século XX. É postura inovadora por considerar as dimensões - formal e documental - concomitantemente, através duma relação dialética.

Entre os expoentes dessa linha de pensamento estavam Renato Bonelli, Piero Gazzola e Roberto Pane. Suas discussões dialogavam com as propostas teóricas de Brandi, oferecendo meios para questionamentos e aprofundamentos recíprocos ${ }^{33}$. A esse contexto de discussões se associavam também Philippot e Lemaire.

A Carta de Veneza é herdeira direta do restauro crítico e, indiretamente, também da teoria brandiana. Roberto Pane, na conferência de abertura do Congresso de Veneza, fez referência explícita aos preceitos teóricos de Cesare Brandi, que em 1963, ano anterior ao congresso, havia publicado dois textos de fundamental importância: o verbete "Restauro", na Enciclopedia Universale dell'Arte; e Teoria da Restauração. Pane fez uma longa digressão, em plena concordância com os princípios de restauração contidos no verbete ${ }^{34}$, interpretando-os para o campo da restauração arquitetônica ${ }^{35}$.

Já nas palavras de Bonelli, o restauro é encarado essencialmente como "ato de cultura", com consciência de lidar com bens únicos e não reproduzíveis, portadores de conhecimento em vários campos do saber, que são suporte identitário das culturas e que, portanto, devem ser tratados de maneira ética e com rigor ${ }^{36}$. O restauro assume ainda a denominação "crítico", pelo fato de a ação ser entendida fundamentalmente como ato crítico - que perscruta a obra do ponto de vista formal, documental e material, respeitando suas várias fases e as marcas que a passagem do tempo depositou sobre a obra -, alicerçado nos instrumentos oferecidos pelo pensamento crítico e científico do momento, em especial pela estética e pela história. Trabalha com plena consciência de que qualquer ação é sempre ato do presente, que não propõe uma reversibilidade do tempo, e que intervém na realidade figurativa do bem, controlando e prefigurando as transformações.

A análise da obra, como mencionado, é alicerçada na relação dialética entre as instâncias estética e histórica, algo que faz com que cada caso deva ser analisado em suas particularidades e não recaia em categorias pré-determinadas (como ocorria em algumas proposições de Giovannoni). $\bigcirc$ restauro coloca-se como "processo crítico em ação" 37 , pois, ao processo crítico, segue a fase operacional, que se insere na obra como uma "hipótese critica" 38 ,
26. Discussões sobre a carta aparecem recorrentemente em reuniões científicas do Icomos. Vale lembrar alguns números monográficos como Icomos-Wallonie, (1994); Icomos (2004).

27. A Declaração de Compromisso Ético para os membros do Icomos reitera a validade e pertinência da Carta de Veneza. O texto foi revisto em 2002, e está disponível em: <www.icomos.org>

28. Lista disponível em: $<$ www.international.icomos.org/chartes.htm>, consultada em 14 jan. 2010.

29. Ver em Icomos (1971) os países representados e a lista completa dos participantes nas atas do Congresso. O documento está disponível em: $<$ http://www.international. icomos.org/publications/ homme.htm>, sítio do Icomos.

30. Uma síntese das discussões e dos pontos de divergência está no texto de Lemaire (1971, p. 147-152), relator do Congresso, que faz uma análise geral dos trabalhos e, no que concerne especificamente à redação da Carta, mostra os aspectos de continuidade e as diferenças em relação à Carta de Atenas. Para uma ideia mais precisa do que foi sintetizado na Carta em relação às ideias que circulavam durante o Congresso, ver, em Icomos (1971), que contêm as várias apresentações.

31. Isso ocorre em qualquer encontro científico. Também durante a conferência que deu origem à Carta de Atenas é possível notar uma grande divergência entre o que é a versão final da Carta, marcada pela visão do chamado "restauro filológico" de Giovannoni, que deu contribuições fundamentais à sua redação, e as variadas formas de tratamento de monumentos históricos, como transparecem em muitas apresentações que constam 
das atas (OIM, 1933). Ver, por exemplo, em OIM (1933, p. 80-83), as colocações do belga Paul Saintenoy que, mesmo preconizando a prudência, a não-modificação da obra, o respeito pela pátina, admite que, se partes do edifício tiverem desaparecido, devem ser restituídas em seu estado primitivo, desde que a ação seja embasada em documentos seguros, algo que não é admitido na formulação da Carta de Atenas. Por outro lado, o mesmo autor recomenda que, na falta de documentação, o edifício seja deixado incompleto.

32. Ver Piero Gazzola e Roberto Pane (1971).

33. Para as discussões do pe ríodo, da relação entre restauro crítico e teoria brandiana, $\mathrm{e}$ bibliografia complementar, ver Giovanni Carbonara (1997, p. 271-340); e Beatriz M. Kühl (2009, p. 59-80). Ver ainda as formulações de protagonistas como Renato Bonelli $(1959 ; 1983$; 1995); Cesare Brandi $(1950 ; 1954$ 1956; 1983; 1966; 2004); Roberto Pane (1948; 1967; 1987); Albert Philippot e Paul Philippot (1959; 1960); ou só deste último (1966; 1976).

34. Cf. Roberto Pane (1971, p. 1-12). Ele critica, porém, vários aspectos do verbete Restauro architettonico, de Renato Bonelli, publicado, a convite de Brandi, na mesma enciclopédia (Bonelli, 1963). Pane interpreta as colocações de Bonelli na enciclopédia (ao discutir a prevalência do valor artístico sobre o histórico em caso de conflito), como se este tivesse negado a simultaneidade e a relação dialética entre eles, dando preponderância absoluta ao valor artístico em detrimento do histórico, o que conduziria a uma intervenção liderada pela livre escolha e não por um fundamentado juízo crítico (ver em especial, p. 4-6). Refuta ainda as colocações de Bonelli sobre a criatividade ne- justamente por assumir que a ação é fruto do reconhecimento e da reflexão de um dado período. A ação não deve inviabilizar intervenções futuras, pois mudanças de situação, a existência de uma crítica mais bem esclarecida ${ }^{39}$ ou muito diversa, ou de técnicas mais adequadas, podem tornar necessário - ou oportuno - intervir novamente da obra.

Mas as especificidades que são reconhecidas para os casos particulares, "o cada caso é um caso" (em vista da conformação da obra, de seus materiais e de suas vicissitudes ao longo do tempo), não devem ser confundidas com "cada um faz o que quer". A intervenção deve seguir princípios fundamentais (e não, regras) que norteiam o campo da restauração como um todo, derivados das razões por que se preserva, e que devem embasar o código de conduta dos profissionais envolvidos na área. $\bigcirc$ intuito é afastar o restauro de um empirismo pedestre e vinculá-lo ao pensamento crítico e científico do momento em que é feita a intervenção ${ }^{40}$. A atuação, em vez de partir, como ocorria antes, de uma via empiricamente induzida a partir do objeto, passa a ser pautada numa via deduzida a partir de fundamentação ética e científica, voltada a todos os tipos de manifestação cultural, para depois abordar as particularidades de cada obra.

Provêm desse raciocínio os preceitos teóricos da restauração, presentes na Carta de Veneza, que deveriam reger a ałuação prática. Esses princípios derivam de um processo plurisecular, com origens no século XV, de transformação das relações entre um dado presente histórico e bens de épocas anteriores, reconhecidos como de interesse cultural, fazendo com que as ações não mais sejam motivadas, unicamente, por questões práticas (de uso, econômicas etc.). $\bigcirc$ que move as intervenções são questões de cunho cultural (aspectos estéticos, históricos, memoriais e simbólicos dos bens), científico (o conhecimento que as obras transmitem nos vários campos do saber, sejam humanidades ou ciências naturais), e ético, por não se ter o direito de apagar os testemunhos de gerações passadas tidos como relevantes, e de privar o presente e as gerações futuras de bens portadores de elementos identitários (aspectos memoriais e simbólicos), além da possibilidade de conhecimento que eles podem transmitir. Assim, deixam de ser prevalentes as questões de ordem prática, apesar de sempre presentes, e passam a ter caráter indicativo, mas não, determinante. São empregadas como meios de preservar, mas não como a finalidade, em si, da ação.

Os preceitos teóricos da restauração - que guiam o modo de intervir em bens de interesse cultural - são relacionados diretamente com aquilo que motiva a preservação. São devedores de pelo menos dois séculos e meio de formulações teóricas, associadas a experimentações sistemáticas, na prática, e a propostas legislativas; e de um século em que a restauração é entendida como campo disciplinar autônomo, mas não isolado - sendo, muito antes pelo contrário, necessariamente multidisciplinar. A restauração possui, portanto, referenciais teórico-metodológicos e instrumentos técnico-operacionais que lhe são próprios.

A forma como os princípios essenciais da restauração - nomeadamente a distinguibilidade da ação contemporânea, a mínima intervenção, a retrabalhabilidade, e a compatibilidade de técnicas e materiais - são, ou não, absorvidos na Carta de Veneza, na atualidade, é analisada no item que se segue. 
Como mencionado, a Carta de Veneza é um documento sintético, que apresenta algumas indicações; é diferente, pois, da Teoria da Restauração, de Brandi, que é formulação de maior complexidade e envergadura, oferecendo bases filosóficas de atuação ${ }^{41}$. Esse sintetismo e a dificuldade de aplicação direta, na prática, desses preceitos originaram reflexões de grande interesse nos anos 1970. Exemplos são dados pelas bem-sucedidas experiências na Hungria, baseadas numa leitura fundamentada da Carta de Veneza e analisadas por Miklós Horler no primeiro número do Boletim do lcomos $^{42}$. Horler enfatiza o papel inovador da Carta de Veneza, ao reiterar princípios essenciais da Carta de Atenas, associando-os a formulações mais amplas, por conta da crise metodológica gerada pela Segunda Guerra Mundial. Obtém-se, então, um corpo doutrinário rigoroso, mais consistente, voltado a uma unidade de conduta. Horler condena as reconstruções abusivas e as grandes confusões que esses atos causam, mostrando que, na Hungria, houve renúncia às tentativas de reconstruir aquilo que não pode ser ressuscitado. Informa que, aí, nenhum monumento histórico, completa ou parcialmente destruído na Guerra, foi reconstruído. No país, a Carta de Veneza foi bem acolhida, tendo profunda ressonância em diretrizes estabelecidas pela Academia de Ciências da Hungria. Analisa as formas como, em diversas intervenções, os artigos da Carta foram interpretados com rigor conceitual, abordando a questão do uso, dos completamentos de obras mutiladas, a conservação e valorização de ruínas, a preservação das várias estratificações das obras arruinadas ${ }^{43}$.

Outro exemplo relevante é dado pelos questionamentos feitos durante reunião do Icomos-França em Paris, em 1976, no colóquio intitulado As restaurações francesas e a Carta de Veneza. Foram extensamente debatidos aspectos teóricos e suas repercussões operacionais, notando-se a grande dificuldade em traduzir os princípios-guia da Carta numa prática fundamentada. Algumas críticas parecem advir, por um lado, da dificuldade de compreensão do papel das cartas, com seu caráter essencialmente indicativo, e, por outro, de interpretações feitas sem conhecimento mais profundo dos debates que se travavam naquele período e que embasam as proposições do restauro crítico. Exemplos são dados pelos questionamentos feitos por Michel Parent ${ }^{44}$ ou Yves Boiret, no que respeita ao uso. Alguns autores, por fazer uma leitura literal-restritiva do texto, consideravam que a Carta comportaria riscos de mumificação. Mas, após as discussões dos vários grupos de trabalho, a conclusão geral foi: "a carta de Veneza nem sempre oferece uma resposta clara a problemas concretos, infinitamente variados, mas, tal como é, constitui, no entanto, um guia útil para a reflexão. Pode ser que seja o caso de fazer emendas ou de completá-la em determinados pontos, mas seria um erro, aos olhos dos participantes do colóquio, querer modificá-la de maneira profunda"45.

No Brasil, a Carta é citada com frequência, mas não analisada na mesma medida. Apesar de haver representantes brasileiros no evento de Veneza - a exemplo de Wladimir Alves de Souza, da Universidade de Brasília46 - a discussão do documento, de maneira mais sistemática, só ocorreria na década seguinte. Um marco foi o curso de restauração e conservação de monumentos cessária na restauração, considerando-as como um incitamento à criatividade arbitrária, não condicionada pela análise da obra. Apesar da polêmica sobre o enunciado de Bonelli, o que se buscava no período, nas obras de ambos os autores, era uma atenção maior aos valores figurativos da obra, sem desrespeitar, porém, seus aspectos documentais Bonelli, por sua vez, via a Carta de Veneza como formulação de cunho essencialmente positivista, de caráter ainda giovannoniano e oitocentista, por não levar em consideração as formulações da estética, especialmente aquelas de matriz crociana. Desse modo, afirma que o documento não leva em conta as aquisições das duas décadas precedentes sobre o restauro fundamentado no juízo crítico. Para uma análise ponderada dessa polêmica, ver Giovanni Carbonara (1976, p. 43-73). Já Marco Dezzi-Bardeschi (2004, p 432-437) comparece com uma leitura diversa.

35. Mais do que a Carta de Veneza, a Carta Italiana de restauração, de 1972, é uma tentativa direta de leitura dos princípios brandianos para várias formas de manifestação de interesse histórico-artístico, inclusive arquitetura. A Carta de Veneza é voltada para o patrimônio arquitetônico, mas parte de uma visão unitária do restauro e do pressuposto de que existem princípios comuns para todas as manifestações culturais, interpretando-os para o caso arquitetônico; cf. Roberto Pane (1971, p. 2-3). É comum, no Brasil, falar que a teoria brandiana foi feita para obras pictóricas e escultóricas, e não é aplicável à arquitetura. Isso é desmentido pelos próprios exemplos arquitetônicos existentes na Teoria; as formulações ali contidas se voltam para todos os tipos de produção artística. Isso não quer dizer que, para o caso das edificações, sejam de in- 
terpretação simples, mas existem trabalhos bem-sucedidos, contemporâneos a Brandi, como as intervenções de Franco Minissi. Giovanni Carbonara evidencia, através de conceitos e da análise de obras restauradas, que a teoria brandiana foi $\mathrm{e}$ continua a ser aplicada na prática, inclusive para a arquitetura moderna, em especial no que concerne ao restauro do arranha-céu da Pirelli, em Milão, conduzido segundo sólidas premissas teórico-metodológicas (e com excepcional adequação operacional), com raízes no pensamento de Brandi e no restauro crítico; ver Giovanni Carbonara (2006)

36. Cf. Renato Bonelli (1959, p. 13-29).

37. Cf. Renato Bonelli (1995, p. $57 ; 69)$.

38. Cf. Cesare Brandi (1954, p. 47).

39. Ver Albert e Paul Philippot (1959).

40. Brandi, reiteradas vezes, manifestou-se contra ações baseadas no empirismo e no arbítrio de um único restaurador, como na própria Teoria da Restauração: "retiramos para sempre a restauração do empirismo dos procedimentos e a integramos na história, como consciência crítica e científica do momento em que a intervenção de restauro se produz"; cf. Cesare Brandi (2004, p. 100)

41. A Teoria não é, porém, nem um manual prático, nem um texto teórico desvinculado da prática, pois apresenta essencialmente formulações teóricas verificadas ao longo de duas décadas em intervenções concretas. Bonelli, segundo Giovanni Carbonara (1995, p. 59-60), "sempre se recusou considerar as Cartas de 1931 e 1964 (e ainda menos aquela de 1972 , mais diretamente marcada pelas espe arquitetônicos, de 1974, organizado pela FAU-USP, em cooperação com Iphan e Condephaat. A Carta de Veneza fazia parte da bibliografia utilizada por Hugues de Varine-Bohan, que lecionou no curso. Nas aulas de Augusto da Silva Telles, a Carta foi extensa e fundamentadamente perscrutada ${ }^{47}$, mas o arquiteto Fernando Machado Leal, que foi professor do curso e dizia seguir as recomendações das Cartas de Atenas e de Veneza, define restauração como "fazer voltar a edificação à sua feição primitiva"48, em flagrante contradição com as definições de ambas as cartas. Essa inconsistência teórica persiste até mesmo em instrumentos normativos recentes, como a decisão normativa n. 80, do Conselho Federal de Engenharia, Arquitetura, Urbanismo e Agronomia (Confea), de 2007, que afirma basear suas definições em documentos como a Carta de Veneza e a Carta de Lisboa, sem se dar conta de que as definições desses documentos são incompatíveis entre si, pois, neste último documento, restauro é definido como "obras especializadas, que têm por fim a recuperação e consolidação de uma construção, assim como a preservação ou reposição da totalidade ou de parte de sua concepção original ou correspondente aos momentos mais significativos da sua história"49. Ou seja, ainda persiste, no Brasil - apesar de algumas honrosas exceções, como o esforço de Silva Telles -, uma enorme dificuldade de leitura fundamentada do documento de Veneza.

Os desdobramentos teóricos da restauração de monumentos históricos na atualidade, apesar de multifacetados, não se colocam como uma superação dos postulados contidos na Carta e daquilo que tem caracterizado o debate no campo. Houve, nos anos 1960, certa convergência das várias correntes existentes em relação aos princípios contidos na Carta; hoje, há um distanciamento um pouco maior.

Nas atuais discussões sobre o tema (em âmbito italiano, onde a discussão teórica é associada de modo mais evidente às ações práticas), verificam-se três tendências principais: a "crítico-conservativa", herdeira direta do restauro crítico e da teoria brandiana; a "conservação integral"; e a "hipermanutenção-repristinação" 50. Na conservação integral, a instância histórica é privilegiada e não interage com a instância estética através da dialética, pois a conformação do bem é entendida como decorrente da passagem do objeto pelo tempo, e, portanto, a matéria deve ser preservada tal qual chegou aos dias de hoje. Uma ação como a remoção de adições (como prevista no artigo $11^{\circ}$ da Carta de Veneza), por exemplo, não é preconizável. Para o restauro crítico-conservativo, as instâncias estética e histórica são analisadas do ponto de vista metodológico, interagindo através de dialética, mas não são destacáveis são aspectos coexistentes e paritários. A conservação integral parte de releituras, da historiografia, que questionam a existência de testemunhos mais relevantes do que outros para a história. Para hierarquizar remanescentes do passado, seria necessário um conhecimento total da história, inquestionável ao longo do tempo, algo negado pela reflexão historiográfica. Juízos de valor são relativos, e o conhecimento do passado é limitado e, sempre, uma construção do presente. Por não existir juízo crítico "infalível", não se deveria julgar. $\bigcirc$ documento deve, portanto, ser preservado em sua integridade, mesmo que a configuração da obra 
seja conflituosa. Na vertente crítico-conservativa, o juízo deve ser necessariamente baseado na historiografia e na estética, para ser de fato juízo fundamentado e não ato arbitrário, com plena consciência de que qualquer ação é fruto do presente e sua pertinência é relativa; em relação ao restauro crítico, em função do alargamento do que é considerado bem cultural, essa tendência é mais prudente, mais "conservativa", atribuindo interesse a testemunhos mais variados do que os aceitos nos anos 1960. Mas as duas vertentes excluem possibilidades de imitação ou mimetismo e dão importância primordial aos procedimentos de manutenção e tratamento das patologias ${ }^{51}$. Para a conservação integral, o projeto de transformação de uma obra arquitetônica é, do ponto de vista metodológico, uma etapa distinta: existe a fase de conservação, que respeita integralmente a obra tal como chegou ao presente; e existe a fase de inovação, que é posterior à conservação e assemelha-se ao projeto do "novo", com grande liberdade expressiva. Difere, pois, da corrente crítico-conservativa, em que se articulam, do ponto de vista metodológico, os momentos conservativo e de inovação. A terceira vertente, a hipermanutenção, propõe o tratamento da obra através de manutenções ou integrações, retomando formas e técnicas do passado. A vertente crítico-conservativa e a conservação integral valorizam a diversidade, enquanto, na manutenção-repristinação, existe um pragmatismo de base, com maior tendência a trabalhar por analogia ${ }^{52}$.

Apesar das várias visões que caracterizam o debate teórico atual, não houve inovação de monta em relação aos debates existentes anteriormente, como ocorreu entre Atenas e Veneza, com a incorporação da "instância estética" nas ações de restauro. Na atualidade, as tendências da restauração são devedoras dos debates dos últimos dois séculos e, apesar de proporem releituras que apresentam ineditismo, não se colocam como renovação radical ou superação das propostas anteriormente existentes. Ocorre, ainda, um enorme alargamento daquilo que é considerado bem de interesse cultural, e a Carta de Veneza, obviamente, não se deteve em todos os tipos de manifestações culturais; daí os documentos integrativos que se seguiram à Carta, no próprio lcomos, facilitados pela visão unitária do restauro, como proposto em Veneza. Desse modo, aspectos que eram apenas mencionados ou implícitos na Carta, passam a ser trabalhados de maneira mais explícita, como o caso das cidades históricas (1987), de sítios patrimoniais (2008), de elementos estruturais do patrimônio arquitetônico (2003).

Michele Cordaro, examinando a Carta italiana de Restauração de 1972, considera seus princípios fundamentalmente válidos e que seriam necessários, na verdade, não outros documentos de mesmo cunho, mas capítulos que especificassem questões técnicas e operacionais ${ }^{53}$. Carbonara estende tal raciocínio para a Carta de Veneza, considerando-a essencialmente válida, instrumento a não ser substituído ${ }^{54}$. Afirma que as transformações recentes do campo não são inovadoras, mas partem da base de discussões que se intensificaram do século XIX em diante; no que respeita à tendência a que o próprio autor é filiado, o restauro crítico-conservativo, mostra como a tendência tem suas raízes no restauro crítico, interpretadas para um âmbito mais alargado daquilo que passou a ser considerado bem cultural lque é algo compatível com culações brandianas) como formulações teóricas que espelhavam limpidamente as aquisições do momento, mas as julgava como honráveis compromissos. Não expressão de absoluto rigor conceitual, mas produtos de ajustes empíricos, de pacientes negociações, desenvolvidas com inegável inteligência através da luz refletida à distância de predileções conceituais e metodológicas".

42. Cf. Miklós Horler (1971, p. $52-54 ; 72)$.

43. Idem, p. 56-124.

44. Michel Parent (1977, p. 10 ), por exemplo, ao mencionar o fato de a restauração ter por objetivo revelar os valores estéticos e históricos do bem, e parar onde começarem as hipóteses, questiona por que a Carta define o restauro como um recurso excepcional, uma vez que a própria Carta estipula aqueles objetivos como meta a ser atingida. Na verdade, a Carta estabelece os objetivos gerais para a conservação e para o restauro, que são parte de um mesmo processo, fazendo a distinção quantitativa (e não qualitativa) entre manutenção, conservação e restauro. Esses objetivos devem ser atingidos em qualquer intervenção em monumentos históricos.

45. Cf. Jean Chatelain (1977, p. 8).

46. Ver Icomos (1971).

47. Cf. Lia Mayumi (2008, p. 148-155).

48. Cf. Fernando Machado Leal (1977, p. 131).

49. A Carta de Lisboa, cuja denominação completa é Carta da Reabilitação Urbana Integrada de Lisboa, não é bem aceita por muitos profissionais portugueses, por causa dos equívocos conceituais de algumas de suas definições, tendo pouca relevância 
no país e nenhuma relevân cia europeia. É resultante do I Encontro Luso-brasileiro de Reabilitação Urbana - Centros Históricos, organizado pela Câmara Municipal de Lisboa, em 1995. Além da definição supracitada, admite também a reconstrução de edifícios. Infelizmente, foram definições dessa natureza, sem coerência conceitual, sem raízes na reflexão crítica no campo do restauro como historicamente construído, que deram base à decisão normativa $\mathrm{n}$. 80 , de 25 de maio de 2007 , que define a ação em bens culturais, e à resolução n. 1010, do Confea, de 22 de agosto de 2006 , que estabelece normas para a atribuição profissional para arquitetos e urbanistas no setor de atuação do patrimônio cultural.

50. Segundo a interpretação de Carbonara e Miarelli Mariani. Para esses temas, ver Giovanni Carbonara (1997); Beatriz M. Kühl (2009, p. 81-100); e Gaetano Miarelli Mariani (2000).

51. Para os textos de autores vinculados à conservação integral, ver Amedeo Bellini (2003); Marco Dezzi-Bardeschi (2004); e Anna Lucia Maramotti-Politi (1996).

52. O mais conhecido dos defensores dessa vertente no Brasil é Paolo Marconi (1993; 1999).

53. Ver Michele Cordaro (1989).

54. Cf. Giovanni Carbonara (1995, p. 60-61).

55. Cf. Raymond Lemaire (1999, p. 191-193).

56. Idem, p. 193.

57. Que vem do verbo latino monère, advertir, chamar a atenção para, fazer observar, com raiz "mem" (da qual deriva também memìni, ter presente no espírito, recordar-se, lembrar-se de alguma coisa), daí "monumento" os enunciados da Carta de Veneza). Desse modo, acredita não ser mais o momento de sínteses elegantes, como em Veneza, e que o interesse seria elaborar propostas interpretativas (para a concepção alargada de bens culturais, algo que - Icomos tem feito a partir de suas cartas integrativas) e aplicativas, aprofundando aspectos técnicos e de execução, e envolvendo procedimentos de projeto e de licitação.

Lemaire, em seu artigo É necessário rever a Carta de Veneza? (1995) 55 , lança uma série de questionamentos sobre a Carta. Mas, longe de querer desqualificá-la, seu texto é um apelo por análises pautadas pelo rigor.

Nele, Lemaire relembra as discussões que deram origem à Carta, mencionando que foi acolhida pela quase totalidade dos votos: houve uma única exceção - significativamente, o voto dos Estados Unidos. Naquele período, ingenuamente se acreditava, diz ele, que a filosofia a embasar o texto tinha um valor universal, mesmo os participantes sendo, em sua maioria, ocidentais e os principais autores do documento serem filiados à mesma doutrina. Desde então, porém, o mundo e a noção de cultura alteraram-se muito, e uma carta é a repercussão do estágio das ideias de um determinado momento. Reconhece que a Carta se coloca de maneira fundamentada em relação a dois extremos, mas, com frequência, não foi, infelizmente, respeitada na prática: por um lado, as reconstituições hipotéticas, repudiadas pela Carta, continuaram a ocorrer; por outro, o artigo 9․, em que se afirma que a composição deverá ostentar a marca de seu tempo, foi muitas vezes abusado, acabando por fazer com que a essência da ação fosse a intervenção contemporânea.

Em virtude das mudanças ocorridas com o tempo, muitas delas não previsíveis quando da redação da Carta, surgiram com frequência, nas reuniões do Icomos, questionamentos, mas o organismo sempre reiterou a validade dos princípios da Carta, elaborando documentos de integração e aprofundamento. Sobre essa atitude "conservadora" da entidade, Lemaire considera que se baseia em três fatores: a Carta contém valores que continuam atuais; a maioria dos membros do órgão não se conscientizou de outras formas de salvaguarda, como praticadas tradicionalmente em outras culturas; a unanimidade obtida com a Carta de Veneza dificilmente ocorreria para um novo texto ou, mesmo, para o texto revisto. Reconhecendo que a Carta não mais pode ser considerada como atribuída do valor universal a ela creditado anteriormente, o autor recomenda que se trabalhe, em relação a esse aspecto, com prudência e sapiência, com abertura em relação à concepção dos outros e "sobretudo com grande rigor ético e intelectual" 56 .

Justamente esse ponto - o valor não-universal da Carta - ocupava as reflexões de Lemaire em seus últimos anos, e é analisado a seguir, procurando evidenciar que a Carta continua, sim, válida para guiar intervenções em "monumentos históricos", mas não é válida para todo e qualquer "monumento". Esse é um tema a ser analisado com extrema atenção e cautela: a Carta de Veneza é documento que se volta aos "monumentos históricos", como definidos por Alois Riegl no início do século XX. Riegl faz distinção entre "monumentos", entendidos no sentido etimológico da palavra ${ }^{57}$, como elementos de rememoração, 
ou seja, artefatos-instrumentos da memória, feitos para celebrar fatos, datas, pessoas, ritos, crenças; e "monumentos históricos", que Françoise Choay mostra ser construção europeia (catalisada a partir do Renascimento e que se acelera ainda mais a partir de fins do século XVIII, com raízes na consciência adquirida da "ruptura" entre passado e presente) ${ }^{58}$, voltada a bens - tivessem eles sido feitos ou não, em sua origem, com intenções memoriais - que, com o tempo, adquiriram significação cultural. Essa noção foi também apropriada por outros ambientes culturais. É necessário recordar que, por "monumento histórico", não se deve entender obra grandiosa de valor artístico e histórico excepcional (como foi frequente no século XIX), mas, sim, como propõem variados autores na atualidade, qualquer artefato que adquiriu significação cultural com o tempo, - algo mais relacionado ao seu sentido etimológico e às propostas de Riegl.

A relação com os "monumentos históricos" é pautada no respeito pela matéria, como transformada pelo tempo. Essa postura tem relações diretas com um tipo de visão sobre o transcorrer do tempo, uma visão linear, de origem judaico-cristã, em contraposição a uma noção de circularidade do tempo ${ }^{59}$. As culturas que depois se "apropriam" da noção de monumento histórico, são culturas que, em relação ao tempo, têm visão de linearidade: o tempo que não pode ser revivido e revertido e, por isso, esse respeito pela matéria que carrega consigo o transladar da história. Esse tipo de visão predomina em países ocidentais, é bem verdade, mas não se limita ao ocidente, bastando verificar as diferentes posturas em relação à noção de tempo (e à matéria) entre o budismo e o xintoísmo no Japão, como evocado pela mesma Choay. Portanto, não se trata de eurocentrismo, ou de mera oposição ocidente-oriente, mas de distintas relações de variados grupos culturais com a noção de temporalidade.

Em 1994, no Congresso de Nara sobre a autenticidade, o que muito se discutiu - e nem sempre com clareza - foram essas diferentes aproximações ao problema. De fato, algumas manifestações culturais pautadas pela noção de circularidade do tempo não são contempladas pelos postulados da Carta de Veneza.

Foi feito um grande esforço para, devidamente, reconhecer como bens culturais esses artefatos, que "monumentos históricos" não são, para poder incluílos na lista do Patrimônio Mundial da Unesco, cujos critérios de inscrição eram fundamentados na noção de autenticidade ${ }^{60}$. Daí os debates reiteradamente invocados naquele encontro de Nara sobre a reconstrução periódica dos templos xintoístas em lse.

Acerca desse exemplo, Choay posicionou-se de maneira clara:

Assim, a prática periódica do desmantelamento ritual, seguida de reconstrução de forma idêntica, como continua em vigor no templo de Ise (reconstruído ainda uma vez em 1994) nos parece incompatível com a noção de conservação: essencialmente por que não fazemos a distinção entre monumento e monumento histórico. No caso, o templo de Ise é um monumento, bem vivo: na visão de mundo Xintó sua destruição periódica é necessária ao seu funcionamento; ela é exigida como um ato de purificação não somente do local sobre o qual foi edificado, mas também da matéria corruptível (a madeira) de sua estrutura. $\bigcirc$ que Riegl denominava valor de integridade do monumento (Geschlossenheit) é, no caso, indispensável também do latim monumēntum, monimēntum, e molimèntum, $-i$, aquilo que traz à memória, o que faz lembrar. Ver António Gomes Ferreira (1991); e Fundação Antônio Houaiss (2007).

58. Ver Françoise Choay (1995).

59. A linearidade do tempo deve ser entendida, aqui, como contraposição à visão de circularidade; ou seja, uma noção de temporalidade associada à ideia de que o tempo não volta atrás, e não como uma percepção "achatada" da temporalidade, de mera sucessão cronológica, contestada pela historiografia recente. Sobre essas diferentes visões do tempo e algumas de suas implicações culturais, além de bibliografia complementar, ver Jacques Le Goff (2003).

60. A Convenção do Patrimônio Mundial, adotada pela Unesco em 1972, estabelecia a criação de um Comitê do Patrimônio Mundial, que tinha por função definir critérios para inscrição na lista do Patrimônio Mundial. Em 1977, o Comitê determinou que, para a inscrição de um bem na lista, o bem respondesse a quatro critérios de autenticidade: desenho, material, execução e ambientação. 
61. Cf. Françoise Choay (1995, p. 111).

62. A versão em vigor é a de 2008; ver Unesco (2008).

63. Ver Françoise Choay (1995).

64. Cf. idem, p. 106. A visão de Choay provocou muitos debates, durante e depois do evento, por colocar a nu as dificuldades de se trabalhar com essa palavra. Lemaire, que em seu texto sobre autenticidade colocava outra série de questionamentos, acreditava que a postura de Choay levaria a preservação a uma situação de impasse. Philippot, por sua vez, em apoio às posturas de Choay, relembra que, no trato dos bens culturais, "autenticidade" virou uma palavra "mágica", que é equivocadamente usada para qualquer finalidade; cf. Icomos-Wallonie (1995, p. 74).

65. Ver Françoise Choay (1995, p. 105). para que seu poder sobre a memória possa operar e permitir a realização dos ritos que recorda. Mais do que a conservação de um mesmo suporte material, é, pois, a das condições simbólicas que importa ${ }^{61}$.

A Unesco, em busca de postura mais inclusiva e na tentativa de acolher uma maior diversidade de manifestações culturais na lista do Patrimônio Mundial, vem reformulando suas Diretrizes Operacionais. Para ser inscrito na lista, continua exigindo que o bem tenha "valor universal excepcional" (outstanding universal value), analisado segundo critérios de autenticidade e de integridade. A autenticidade de um bem depende dos seguintes atributos: forma e desenho; materiais e substância; uso e função; tradições, técnicas e sistemas; localização e espaço; língua e outras formas de patrimônio intangível; espírito e sentimento; e outros fatores externos e internos ${ }^{62}$. Do ponto de vista operacional, esses critérios são complexos e pouco claros, por continuarem a ater-se à palavra autenticidade - complexidade atestada pela lista ter, desde seus inícios, falsos confessos, como - Centro de Québec - e por continuarem a assimilar e confundir monumento e monumento histórico. Em seu texto, há mais de uma década, Choay mostra a dificuldade de trabalhar com a palavra autenticidade, pelas complexas associações que o termo teve, e continua tendo, ao longo da história, preconizando uma crítica epistemológica para o tratamento da questão ${ }^{63}$, essencialmente pelo fato de a autenticidade ter sua origem em atos textuais que emanam de uma autoridade (como expresso no direito Romano e no direito Canônico). A noção de autenticidade, segundo a autora, foi transferida de modo um tanto imprudente ao campo do restauro, apesar de três condições negativas: não provir de uma apreciação subjetiva, mas emanar de uma autoridade institucional (Direito, Igreja, Razão Científica); por não se poder associar a noção de autenticidade a um único significado (e há vários concomitantes, que variam ao longo do tempo), que não pode ser fixado; e, ainda, por tentar aplicar esse termo a objetos que se alteram ao longo do tempo. Para dirimir esses problemas, a autora sugere que não se trabalhe com a noção de autenticidade de modo isolado, mas com uma série temas articulados, e que a noção de autenticidade poderia ter uma utilidade prática, preventiva, se trabalhada com sua antítese, a inautenticidade (falsos, cópias deliberadas) e associada a outras noções complexas, como original, originário, conservação, reprodução ${ }^{64}$. Esse trabalho articulado é necessário para diferenciar, por exemplo, a reconstrução de um "monumento histórico", que é um falso, da reconstrução ritual de um "monumento", ato que deve ser reconhecido como de interesse para a cultura:

A Stoa de Átalo em Atenas é um falso. Em compensação, a reconstrução ritual do templo de Ise [...] não é uma reconstituição. A reconstrução de Varsóvia após a Segunda Guerra Mundial tampouco o é: não se tratava de uma cópia mas de um objeto urbano inteiro, que pode prescindir de seu estado civil, que tem o estatuto de monumento ou de memorial e que funda uma identidade ${ }^{65}$.

excepcional caso de Varsóvia é admitido com justeza na lista do patrimônio mundial lapesar de contrariar os critérios de autenticidade estabelecidos 
pela Unesco, em vigor quando da inscrição), por ser um esforço descomunal de um grupo social para recuperar sua face devastada pelo conflito armado. $\bigcirc$ que foi reconhecido pela Unesco foi o empenho sem precedentes para reconstituir uma identidade, não o valor dos edifícios em si. Varsóvia tem servido de desculpa, em tempos recentes, para justificar reconstruções ao idêntico em seguida a qualquer catástrofe, ou mesmo reconstruções defasadas de bens destruídos na Segunda Guerra Mundial. Antes de mais nada, não é prudente comparar uma cidade que, num conflito armado, perdeu cerca de 65\% de seus habitantes e $85 \%$ de seu patrimônio construído (e a totalidade do centro histórico), com outros eventos em que a destruição foi relativamente restrita ${ }^{66}$. Claro está que, para as vítimas diretas e indiretas do problema, individualmente, a dor da perda é equiparável. Mas, no que respeita à reconstituição de elementos identitários, a questão deveria ser mais matizada. A resposta excepcional, em Varsóvia, veio de uma situação sem precedentes $^{67}$, em que outra ordem de razões - em especial as de cunho psicossocial - sobrepõe-se àquelas culturais, que regem o campo da restauração, e que, numa situação regular, deveriam predominar. $\bigcirc$ próprio Pane admite isso logo na conferência inaugural em Veneza:

Assim [...] por razões que ultrapassam aquelas de nossas teorias, mesmo que válidas, a face do antigo centro de Varsóvia foi recomposta como antes das destruições nazistas, porque a significação que tinha para a nação polonesa não poderia ser substituída e compensada por aquilo que a arquitetura moderna poderia oferecer ${ }^{68}$.

É necessário lembrar, porém, que há, do segundo pós-guerra, exemplares extremamente significativos de lidar com a destruição, que não comportam uma reconstrução "ao idêntico", como os exemplos dados pela catedral de Coventry, ou pela igreja comemorativa ao Kaiser Guilherme I, em Berlim, em que as ruínas foram conservadas como memento dos horrores da guerra e construídas, adjacentes, novas igrejas, também como voto de esperança no presente e no futuro. Algo ligado não apenas à concepção de restauro, mas também a um dos pilares da cristandade, que é a ressurreição num novo corpo.

Em caso de catástrofes recentes, por exemplo, em vez de uma solução apressada e redutora - uma reconstrução ao idêntico, que passa mais facilmente sem discussões e críticas -, o que deveria ser feito é, de pronto, atender às necessidades emergenciais da comunidade, dando meios para que ela possa minimamente se recuperar, oferecendo condições e tempo para poder lidar com suas perdas. Depois, com a ferida em processo de cicatrização, deveriam ser debatidos modos variados de lidar com as perdas, os problemas relacionados com as reconstruções, outras alternativas mais prospectivas e respeitosas em relação às próprias raízes culturais ${ }^{69}$, para que, a seguir, fosse possível chegar a uma escolha mais amadurecida.

No que diz respeito aos critérios Unesco, ainda é necessária uma discussão mais fundamentada da questão e uma problematização do termo autenticidade, que pode trazer mais confusões do que esclarecimentos ${ }^{70}$, sendo urgente trabalhar de modo a distinguir "monumentos" de "monumentos históricos".
66. Cf. Ascensión Hernández Martínez (2007, p. 70-77) para mais dados sobre o caso de Varsóvia. A autora aponta as diversas fases de reconstrução do centro, diferenciando aquela do imediato pós-guerra, daquelas muito mais problemáticas e sem reais justificativas, feitas desde os anos 1970 .

67. Giovanni Carbonara (1997, p. 186) afirma ser uma situação "em que toda uma outra ordem de ideias, em que considerações afetivas, psicológicas, nacionalistas e mesmo políticas intervêm, a pleno direito, de modo a deslocar a questão, mais genuinamente cultural, a um outro campo de natureza social, com todas as consequências e riscos que um tal deslocamento comporta".

68. Cf. Roberto Pane (1971, p. 1).

69. Lembre-se de que até mesmo Brandi, ferrenho opositor de repristinações arquitetônicas, admite sua possibilidade, em casos muito especiais. Caso os elementos faltantes, cujo desaparecimento alterou a espacialidade do ambiente, não tiverem valor como bem cultural, pode ser admitida a reconstrução ao idêntico, pois, mesmo sendo falsos, não são obras de arte, mas ajudam a reconstituir o ambiente, não degradando sua qualidade artística, inserindo-se como "limites espaciais genericamente qualificados"; outra possibilidade seria a construção de novas obras, problema a ser resolvido "com a elaboração, de maneira original, de uma imagem nova". Mas caso os elementos desaparecidos tivessem sido obras de arte, bens culturais importantes para a composição da identidade do ambiente "está absolutamente fora de questão que se possam reconstruir como cópias. O ambiente deverá ser reconstituído com base nos dados espaciais e não naqueles formais 
do monumento que desapareceu"; cf. Cesare Brandi (2004, p. 136-137).

70. As próprias diretrizes da Unesco seriam mais claras se a palavra autenticidade fosse suprimida, sendo exigido que os bens fossem analisados segundo aqueles mesmos atributos (forma e desenho; materiais e substância; uso e função; tradições, técnicas e sistemas; localização e espaço; língua e outras formas de patrimônio intangível; espírito e sentimento; outros fatores externos e internos), inter-relacionando-os. Para uma análise dessa problemática da autenticidade na Unesco e possíveis formas de torná-la operacional, ver Flaviana Barreto Lira (2009).

71. Na transcrição dos trechos da Carta foi utilizada a versão existente no sítio do Iphan. São feitas algumas comparações com as versões em francês, língua do relator do Congresso e da Carta, e também em inglês. Ambas as versões foram consultadas no sítio do Icomos. Os trechos da Carta de Atenas também provêm do portal do Iphan. Ver referências.
Existe, pois, uma diferença abissal entre reconhecer, de modo merecido, legítimo (e tardio), no seio dos organismos internacionais, formas distintas de se relacionar com o tempo e, portanto, também com a matéria, e acolher a diversidade na lista do Patrimônio Mundial da Unesco; e a frouxidão teórica e metodológica que muitas vezes é associada ao problema, quando se ouve: "se japonês pode reconstruir templos, porque nós não podemos?"

Antes de tudo, nem todo japonês reconstroi templos, havendo, no mesmo país, tradições distintas. Depois, a reconstrução é fruto de profundas questões culturais e religiosas, que encaram o tempo de maneira circular, sendo a reconstrução necessária, como visto, por motivos rituais de purificação. Ou seja, não se trata de uma opção momentânea - esse templo deve ser conservado, esse outro reconstruído -, segundo a vontade daquele instante. São visões de mundo mutuamente exclusivas - um grupo cultural ou possui uma visão linear, ou uma visão circular, e isso não é algo intercambiável segundo o sabor dos ventos: é fator ligado a raízes culturais profundas.

A maior parte dos artefatos culturais brasileiros se relaciona com uma visão de tempo que não volta atrás. Reconstruções rituais, de purificação, são ações restritas a determinados grupos, feitas por razões que fundamentam suas práticas culturais e relações sociais. Essas ações, culturalmente justificadas, são totalmente distintas da reconstrução de monumentos históricos, que se constituem em falsos, e também simulacros, que compõem cenários e que, com a escusa de recuperar a face de uma dada comunidade, na verdade está propondo uma solução apressada, redutora, que achata a história e mascara problemas e conflitos, o que, fatalmente, vai induzir numerosos observadores ao engano de confundir as obras reconstruídas com os monumentos históricos desaparecidos.

A visão preconizada neste texto é, portanto, a de que a Carta de Veneza é um instrumento que mantém suas bases essencialmente válidas para o tratamento de monumentos históricos (o que inclui, evidentemente, também bens que eram "monumentos" em sua origem e que, com o tempo, adquiriram significação cultural, tornando-se também "monumentos históricos"). $\bigcirc$ exercício feito a seguir é comentar determinados pontos da Carta, retomando seus artigos e remetendo a uma bibliografia pertinente, com intuito de interpretar suas colocações. A intenção não é esgotar a discussão, mas, principalmente, esclarecer alguns equívocos e lançar bases para debates ulteriores, oferecendo uma visão mais alargada, e não restritiva, do documento, para que possa ser reinterpretado na atualidade.

\section{A Carta comentada ${ }^{71}$}

Carta Internacional sobre conservação e restauração de monumentos e sítios (Carta de Vene$\mathrm{za}, 1964)$

II Congresso internacional de arquitetos e de técnicos de monumentos históricos, Veneza, 1964

Adotada pelo Icomos, 1965 
Portadoras de mensagem espiritual do passado, as obras monumentais de cada povo perduram no presente como o testemunho vivo de suas tradições seculares. A humanidade, cada vez mais consciente da unidade dos valores humanos, as considera um patrimônio comum e, perante as gerações futuras, se reconhece solidariamente responsável por preservá-las, impondo a si mesma o dever de transmiti-las na plenitude de sua autenticidade.

No preâmbulo da Carta ${ }^{72}$, muitos pontos devem ser destacados. Um deles é a caracterização dos monumentos como portadores de "mensagem espiritual do passado", e, portanto, não apenas de dados materiais e de conhecimento (que aparecem mais adiante em outros artigos), mas também de aspectos memoriais e simbólicos.

Outro, refere-se à designação dos monumentos do passado como "testemunhos vivos" de tradições, ou seja, elementos que, no presente, continuam a participar da vida das comunidades, de maneira ativa. Na Carta de Veneza, todos os monumentos são qualificados como "vivos"; não mais aparece a distinção entre "monumentos vivos" e "monumentos mortos" sugerida, por exemplo, por Louis Cloquet $^{73}$. Durante as discussões do Congresso, Luigi Crespi ${ }^{74}$ manifestou-se contra a denominação "vivo" ou "morto", pois um monumento, mesmo que não tenha uso para funções quotidianas (caso de algumas ruínas arqueológicas), faz parte da vida das comunidades e da composição de um ambiente urbano, como local de visitação, por exemplo. Na Carta, é enfatizada, ainda, a necessidade de utilizar um monumento, qualquer que seja a sua destinação ou época de construção, respeitando a integridade da configuração de seus espaços lalgo que reaparece de modo mais explícito no artigo 5ㅇ. São propostos, na Carta, princípios fundamentais que deveriam guiar todas as intervenções, em qualquer tipo de bem, respeitando sua configuração.

Note-se que a preservação é entendida como responsabilidade de todos - e, por isso, também a necessidade de encontrar princípios comuns que guiem as intervenções -, impondo a todos o dever moral, ou, como diria Brandi, o "imperativo categórico como o imperativo moral"75 pela sua preservação. Nesse trecho, explicita-se que as obras devam ser transmitidas na "plenitude de sua autenticidade". Na Carta, porém, não se especifica o que se entende por autenticidade, algo que deu origem a numerosas controvérsias ao longo dos anos, e que trinta anos mais tarde nas discussões do Congresso de Nara, procurou-se dirimir. No congresso de Paris de 1976, alguns autores consideravam que essa autenticidade preconizada pela Carta seria apenas uma autenticidade de efeito, ou de característica das estruturas, algo contra o qual Pane se manifestou veementemente, enfatizando que as ações de restauro devem ser concebidas como "história moderna responsável"76 - em acordo com as colocações de André Chaste ${ }^{77}$ naquele mesmo congresso -, que devem documentar a si próprias, colocando-se contra qualquer prática de repristinação, de reconstruções e, portanto, falsificações ${ }^{78}$. Existe, como mencionado, uma aproximação, que não é fortuita, com a teoria brandiana; as propostas vão no sentido de discutir princípios gerais - que partem de uma visão unitária para as várias formas de manifestação artísticas, interpretando-as para a arquitetura -, que depois se traduziriam em "técnicas particulares, através das quais as intervenções mais
72. Há um rascunho do preâmbulo da Carta de Veneza, muito semelhante à versão definitiva, escrito de próprio punho por Philippot, guardado nos Arquivos de Lemaire, na Katholieke Universiteit Leuven, Lovaina, Bélgica; cf. Iccrom (2009, p. 9).

73. Ver Louis Cloquet (1901).

74. Ver Luigi Crespi (1971).

75. Cf. Cesare Brandi (2004, p. 31)

76. Ver Roberto Pane (1976).

77. Ver André Chastel (1977).

78. Roberto Pane fez artigo sintetizando as principais colocações do Congresso de Paris, analisando-as de modo crítico; ver Roberto Pane (1976). Quanto ao texto do Congresso de Veneza, ver a Conferência introdutória em Roberto Pane (1971). O autor sempre se contrapôs a reconstruções, como a da Stoa de Átalo, em Atenas; $c$. Roberto Pane (1987, p 310-316). 
79. Cf. Roberto Pane (1971, p. 2).

80. Essa interpretação de autenticidade é reiterada pela Carta para a conservação e restauro do patrimônio construído, conhecida como Carta de Cracóvia, de 2000. O documento é o resultado do trabalho conjunto de várias universidades europeias que, durante três anos, confrontaram idéias através de numerosos eventos científicos, que também contaram com a participação de representantes não-europeus. Essa carta para a Europa unificada reafirma os princípios básicos da Carta de Veneza e reitera seus objetivos.

81. Cf. Raymond Lemaire (1971, p. 147-152). diversas poderiam encontrar uma fundamentação unitária e coerente"79. Na Carta, a autenticidade deve, pois, ser entendida como respeito pela configuração da obra e pela sua materialidade, como transformadas ao longo do tempo ${ }^{80}$.

É, portanto, essencial que os princípios que devem presidir à conservação e à restauração dos monumentos sejam elaborados em comum e formulados num plano internacional, ainda que caiba a cada nação aplicá-los no contexło de sua própria cultura e de suas tradições.

Aqui, especifica-se o que havia sido colocado acima: o patrimônio, mesmo que pertencente a um país, é patrimônio comum e diz respeito à "unidade dos valores humanos". Deve, portanto, ser encarado como sendo de responsabilidade de todos; assim, os princípios que guiam a sua preservação também devem ser discutidos conjuntamente, mas cabe a cada nação reinterpretá-los segundo suas tradições culturais e integrá-los, da maneira que for conveniente, à sua legislação, algo que nunca foi feito no Brasil. Também por isso a Carta é concisa, pois o que se oferece são indicações gerais, a serem reinterpretadas e adequadas às mais variadas realidades culturais e normativas.

Ao dar uma primeira forma a esses princípios fundamentais, a Carta de Atenas de 1931 contribui para a propagação de um amplo movimento internacional que se traduziu principalmente em documentos nacionais, na atividade do Icom e da Unesco e na criação, por esta última, do Centro Internacional de Estudos para a Conservação e Restauração dos Bens Culturais. A sensibilidade e o espírito crítico se dirigem para problemas cada vez mais complexos e diversificados. Agora é chegado o momento de reexaminar os princípios da Carta para aprofundá-los e dotá-los de um alcance maior em um novo documento.

Há, nesse trecho, a filiação direta e nominal da Carta de Veneza em relação à Carta de Atenas e, ainda, o papel relevante atribuído às cartas e aos órgãos internacionais, nomeadamente o lcom e o centro internacional, atual Iccrom. É reconhecido o contexto de alargamento daquilo que é considerado bem cultural, a crescente complexidade da questão lque se torna mais evidente no segundo pós-guerra) e, portanto, a necessidade de rever temas da Carta de Atenas, para que respondam de maneira mais conveniente às circunstâncias daquele momento. As diferenças entre os dois documentos estão explicitadas no relatório geral do congresso, feito por Lemaire ${ }^{81}$. Algumas delas são retomadas a seguir.

Consequentemente, o Segundo Congresso Internacional de Arquitetos e Técnicos dos Monumentos Históricos, reunido em Veneza de 25 a 31 de maio de 1964, aprovou o texto seguinte:

Definições

Artigo $1^{\circ}$ - A noção de monumento histórico compreende a criação arquitetônica isolada, bem como o sítio urbano ou rural que dá testemunho de uma civilização particular, de uma evolução significativa ou de um acontecimento histórico. Estende-se não só às grandes cria- 
ções, mas também às obras modestas, que tenham adquirido, com o tempo, uma significação cultural.

Neste artigo está especificado o campo de interesse da Carta, propondo uma visão bem mais alargada do que a Carta de Atenas. Note-se que, em vez de "monumentos históricos e artísticos", designação que predominava no século XIX le comparece na Carta de Atenas, voltada a obras de grande interesse histórico-artístico), tem-se aqui um "monumento histórico", que pode ser uma obra arquitetônica ou também um sítio, urbano ou rural, que não tenha necessariamente "valor" excepcional do ponto de vista formal e documental, mas que tenha adquirido uma significação de cunho cultural, que abarca um leque mais amplo de significados (lembrando a expressão "portadores de mensagem espiritual do passado" do preâmbulo). Ou seja, pela definição, o interesse pode voltar-se a bens por seus aspectos memoriais e simbólicos. Não são estabelecidos limites cronológicos e, por isso, a Carta refere-se ao patrimônio construído de qualquer época, inclusive a arquitetura recente. Nesse sentido, é importante relembrar o documento 13, do Congresso de Veneza (a Carta é o primeiro): foi votada uma resolução referente à preservação da Maison du Peuple, em Bruxelas, conclamando as autoridades belgas a fazer o possível para evitar a destruição daquela obra de Victor Horta (que acabou sendo demolida em 1965). Foi preconizada, portanto, a preservação de uma obra recente (1 896-1899), dados os parâmetros dos anos 1960, ademais com uma linguagem art nouveau, que ainda não havia sido "reabilitada" pela historiografia e pela crítica.

Artigo $2^{\circ}$ - A conservação e a restauração dos monumentos constituem uma disciplina que reclama a colaboração de todas as ciências e técnicas que possam contribuir para o estudo e a salvaguarda do patrimônio monumental.

Esse é um ponto essencial, no qual é necessário insistir: conservação e restauração constituem um campo disciplinar autônomo, mas não isolado. A autonomia refere-se ao fato de ter referenciais teórico-metodológicos e técnico-operacionais que são peculiares a esse campo específico. Esse processo é fruto de uma transformação plurisecular, de contínuo intercâmbio entre teoria e prática, com raízes mais evidentes no Renascimento (sempre lembrando que a relação das variadas culturas com obras passadas existe desde há muito), e que, em especial, assume maior consistência em finais do século XVIII e início do XIX - quando se multiplicam as formulações teóricas e experiências práticas, associadas a propostas de inventário e legislação -, mas começa a ser entendida como campo disciplinar autônomo a partir das formulações de Riegl, no início do século $X X^{82}$. O campo é autônomo, mas não isolado, pelo fato de ser necessário trabalhar de modo articulado com vários campos do saber: humanidades, ciências exatas e biológicas. Importante é ainda destacar que não se trata de somatório de competências isoladas, mas de verdadeiros trabalhos multidisciplinares em que deve haver efetiva colaboração entre os campos envolvidos.
82. Ver, no que concerne às contribuições de Riegl para a conformação de um campo disciplinar autônomo, as análises de autores como Margaret Olin (1989); Wolfgang Kemp (1990); Jörg Oberhaidacher (1985). 
83. Cf. Roberto Pane (1971, p. 3).

84. Idem, p. 10

85. O fato de não explicitar a relação com teorias artísticas é uma das razões da crítica de Renato Bonelli à Carta de Veneza. Sobre formulações teóricas do restauro e suas relações com teorias estéticas no século XX, e para referências bibliográficas complementares, cf. Giovanni Carbonara (1997, p 271-390). Ver, também, Giuseppe Basile (2004); e Paolo D'Angelo (2006).
Finalidade

Artigo $3^{\circ}$ - A conservação e a restauração dos monumentos visam a salvaguardar tanto a obra de arte quanto o testemunho histórico.

Aí está um ponto capital da Carta, ao enunciar que o objetivo da intervenção é a salvaguarda dos aspectos formais e documentais - as instâncias estética e histórica de Brandi, invocadas nominalmente por Pane na conferência inaugural. Devem, portanto, ser trabalhados de forma concomitante - nas palavras de Pane, "as duas instâncias operam conjunta e simultaneamente em cada ação"83 - colocando-se de maneira mais abrangente do que na Carta de Atenas, em que a ênfase recaía nos valores documentais. Essa articulação mostrou-se necessária para dar respostas adequadas aos problemas que se tornaram mais evidentes depois da Segunda Guerra Mundial ${ }^{84}$, em função das destruições maciças. $\bigcirc$ que fez com que se propusesse essa mudança foi o fato de, segundo os princípios enunciados em Atenas, o restauro não trabalhar com meios conceituais suficientes para lidar com obras e contextos devastados. No entanto, por ser documento conciso e de princípios gerais, a Carta de Veneza não remete a meios ulteriores. Porém, a discussão sobre estética e teorias artísticas à qual o documento está vinculado aparece nesse texto de Pane ${ }^{85}$.

Note-se que razões econômicas ou de uso não são, de modo propositado, mencionadas como fazendo parte dos objetivos da ação, apesar de estar presentes (ver artigo 5\%), pois a ação é entendida como ato de cunho essencialmente cultural. Em realidade, a preservação de monumentos históricos, como entendida hoje (e desde o século XVIII), é essencialmente ação cultural; as razões de ordem prática (de uso, políticas, econômicas etc.) deixam de ser preponderantes, como ocorria anteriormente, e passam a ter caráter concomitante e indicativo; passam a ser meios para preservar, mas não a finalidade da ação. As formas de atuar em monumentos históricos (e seus princípios, enunciados na Carta de Veneza) derivam dessa visão da preservação motivada por questões culturais, científicas e éticas. Ao respeitar os aspectos documentais e formais, considera-se que a obra continue a ser um documento veraz, que transmite de maneira fidedigna o conhecimento, servindo como efetivo e legítimo suporte também de aspectos memoriais e simbólicos.

\section{Conservação}

Artigo $4^{\circ}$ - A conservação dos monumentos exige, antes de tudo, manutenção permanente.

Esse é um tema retomado da Carta de Atenas, que ali aparecia já no primeiro artigo ("adoção de uma manutenção regular e permanente, apropriada para assegurar a conservação dos edifícios"). Note-se que, na forma como a Carta de Veneza está estruturada, aparecem ações de manutenção - atos quotidianos de execução de pequenos reparos e substituições (substituir telhas ou vidros quebrados, reparar condutores etc.), que podem ser feitos com materiais iguais ou semelhantes aos originais (por não haver ruptura temporal na percepção 
da obra), impedindo que a deterioração se acelere e adiando, ou evitando, intervenções de maior monta -, conservação (artigos $4^{\circ}$ a 8), e restauração (artigos 9ำ a 13\%), que implicam graus crescentes de ingerência nas obras. Segunda a visão de Pane, a diferença entre essas ações "é puramente quantitativa e não qualificativa" ${ }^{\prime 6}$, pois o objetivo de qualquer uma dessas ações é o respeito pelos aspectos documentais e formais da obra. É, portanto, uma visão unitária do problema; na teoria brandiana, essa visão aparece sob um único vocábulo: restauração ${ }^{87}$.

Artigo $5^{\circ}$ - A conservação dos monumentos é sempre favorecida por sua destinação a uma função útil à sociedade; tal destinação é, portanto, desejável, mas não pode nem deve alterar a disposição ou a decoração dos edifícios. É somente dentro destes limites que se devem conceber e se podem autorizar as modificações exigidas pela evolução dos usos e costumes.

A formulação de Veneza retoma e aprofunda a questão como colocada na Carta de Atenas de 1931: "a conferência recomenda que se mantenha uma utilização dos monumentos, que assegure a continuidade de sua vida, destinando-os sempre a finalidades que respeitem seu caráter histórico ou artístico".

$\bigcirc$ artigo $5^{\circ}$. é, porém, de difícil interpretação e dá origem a visões bastante problemáticas. Alguns autores fazem uma leitura restritiva e o desqualificam, algo que pode ser visto em algumas colocações do Congresso de Paris de 1976 e que repercute, inclusive, em textos mais recentes em ambientes francês, ao entenderem que, pelo fato de a Carta de Veneza "proibir" modificações, não é operacional para bens que exigem transformações de maior monta $^{88}$. Claro que há profissionais (entre eles Arquitetos-Chefes de Monumentos Históricos na França) que realizaram interpretações alargadas dessas questões, inclusive em sua repercussão projetual, a exemplo de Pierre Prunet ${ }^{89}$. Nesse sentido é de grande interesse o esforço pioneiro, feito na Hungria e analisado por Horler ${ }^{90}$, de interpretação fundamentada dos postulados da Carta, em especial naquilo que se refere a esse artigo.

Convém proceder com cuidado na interpretação desse artigo $5^{\circ} \mathrm{e}$ tratar de algumas de suas implicações. A primeira delas diz respeito ao papel do uso, numa intervenção de conservação e restauro. Na Carta, o uso é entendido como algo desejável, mas não como o objetivo da intervenção, definido no artigo 3०.: salvaguardar os aspectos documentais e formais da obra. Se o uso não é objetivo da intervenção, mas favorece a preservação da obra, isso significa que o uso é o meio de preservar. Entender a utilização do bem como meio ou como fim, não é um problema marginal - é algo essencial, que tem consequências distintas na forma de abordar o objeto. Para explicitar essa diferença, invoca-se uma comparação citada por Emanuele Severino, para deixar evidente a diferença de se considerar algo como meio ou como finalidade: "comer para viver é algo essencialmente diverso de viver para comer" ${ }^{\prime \prime}$. Ninguém nega a importância da alimentação para a sobrevivência humana, assim como, no campo da restauração, ninguém nega o papel do uso para uma obra arquitetônica continuar a existir. Mas o fato de confundir os meios com os fins denota relação distinta, como, no
86. Cf. Roberto Pane (1971, p. 2).

87. É bom relembrar que existiram, e existem, visões distintas em relação a esse problema. Há autores que veem conservação e restauração como atos inconciliáveis. Retomam, assim, uma polêmica que vem desde o século XIX, aparecendo em formulações de variados autores, como Adolphe Didron, John Ruskin, William Morris, Boito e Riegl. Muitas intervenções feitas no decorrer daquele século tinham caráter invasivo, provocando grande destruição de aspectos documentais das obras (supressão de estratificações consolidadas na conformação do bem, imposição de imagem idealizada e de um suposto estado originário), além de problemas de percepção, pois, de modo violento, uma nova imagem dos edifícios era reinserida na realidade em que ele anteriormente existia. Muitos autores fizeram críticas pesadas em relação às intervenções da época, em que conservação e restauração foram entendidas como opostas. Camillo Boito $(1893$; 2002) vai além: evidencia os perigos da restauração como praticada no período, mas dá passos consistentes para conter a arbitrariedade intervencionista do restauro, para torná-lo uma ação culturalmente fundamentada e legítima. É de Riegl que proveem as bases para superar a oposição entre conservação e restauro, propondo, inclusive do ponto de vista normativo, uma preservação responsável, preferencialmente conservativa, e alicerçada em preceitos coerentes, lançando bases para a autonomia disciplinar do campo. Brandi levaria isso ainda mais adiante, articulando teoria e prática de modo solidário - em especial através de suas formulações teóricas e das práticas do ICR de Roma, que, a partir de 1939, ele dirigiu por cerca de vinte anos -, entendendo o restauro como 
campo disciplinar autônomo que de fato preserva a obra em sua conformação e como documento histórico. É esse o entendimento que perpassa as formulações da Carta de Veneza. Paolo Torsello (2005), vinculado à vertente da conservação integral, organizou um livro buscando confrontar definições de restauro a serem propostas por nove estudiosos atuais. Foi escolhido deliberadamente $\mathrm{o}$ termo "restauro", pois, mesmo a corrente que contrapõe a conservação à restauração, reconhece apenas o restauro como campo disciplinar (e não reconhecem a conservação como tal). Desse modo, Bellini e Dezzi Bardeschi, filiados à conservação integral, definem restauração segundo a visão do que, para eles, é conservação.

88. Exemplo disso é dado por Emmanuel de Roux, ao analisar o patrimônio industrial francês. Ele considera a Carta inoperante para o caso, pois ali se preconiza que se deixem legíveis as diversas fases da história de bens industriais que necessitam de transformações mais incisivas para receber um novo uso; cf. Emmanuel De Roux (2000, p. 26). Já Ponsot (2006) acredita que ainda persiste uma leitura superficial do documento, e que, no país, a discussão de critérios é limitada.

89. Ver Nicolas Detry e Pierre Prunet (2000).

90. Cf. Miklós Horler (1971 p. 56-78).

91. Cf. Emanuele Severino (2003, p. 31).

92. Ver Piero Gazzola e Roberto Pane (1971).

93. Cf. André Chastel (1977, p. 105).

94. Cf. Raymond Lemaire (1971, p. 152) caso da comida, separando alimentação saudável e distúrbios alimentares. Do mesmo modo, na restauração, é possível encontrar um uso compatível e desenvolver - programa de maneira adequada - se o que se quer é de fato preservar como ato de cultura. Isso vai diferenciar um processo de decadência por "inanição" (falta de uso) ou um "distúrbio alimentar" (uso inadequado ou programa desenvolvido de maneira inadequada) de uma "correta alimentação" (que não significa privação), a saber, a preservação por meio de uso compatível com a configuração da obra.

Outra ordem de problemas diz respeito à interpretação daquilo que pode ou não ser modificado para promover a sobrevivência do bem. Alguns autores, como citado, interpretaram o "não pode nem deve alterar a disposição ou a decoração dos edifícios" de modo extremamente restritivo, desqualificando, assim, a Carta como um todo, sem levar em consideração não apenas a Carta em sua inteireza, como também a continuação do próprio artigo, "somente dentro destes limites que se devem conceber e se podem autorizar as modificações exigidas pela evolução dos usos e costumes". Se modificações podem ser autorizadas, significa que é possível alterar; os casos analisados por Horler dão indicações expressivas de como as necessidades contemporâneas (em especial no que diz respeito ao uso habitacional) podem ser contempladas em monumentos históricos, respeitando suas características. É possível alterar, levando em conta os objetivos da intervenção (artigo 3ㅇ), e entendendo o uso como meio e não como finalidade. Na versão francesa da Carta, língua do relator, onde em português está "disposição", consta "ordonnance"; iá na versão inglesa, "lay out". Esse artigo seria mais bem interpretado se as alterações permitidas fossem entendidas como não subvertedoras da ordenação e da articulação dos espaços; ou seja, manter as características de estruturação espacial e fazer o mínimo de alterações necessárias para que o bem possa sobreviver. Gazzola e Pane, em sua proposta de carta, mostram a importância de uma função que seja compatível com as características da obra ${ }^{22}$. Chastel enfatiza que as restaurações devem modificar apenas 0 indispensáve $\left.\right|^{93}$. Em outras palavras, o princípio da mínima intervenção - que significa fazer aquilo que é necessário e suficiente (mínimo não pode equivaler a insuficiente) para que o bem possa continuar a existir -, o que, dependendo da situação, pode exigir uma ação de monta.

Artigo $6^{\circ}$ - A conservação de um monumento implica a preservação de um esquema em sua escala. Enquanto subsistir, o esquema tradicional será conservado, e toda construção nova, toda destruição e toda modificação que poderiam alterar as relações de volumes e de cores serão proibidas.

Este artigo dá mais ênfase à relação monumento e entorno ${ }^{94}$ do que a Carta de Atenas, que recomendava respeitar "o caráter e a fisionomia das cidades, sobretudo na vizinhança dos monumentos antigos" e, ainda, preservar as "perspectivas particularmente pitorescas". Na Carta de Veneza está mais explícita a relação do monumento histórico com seu ambiente, apesar de serem indicações ainda de caráter genérico, não incorporando o entendimento das 
áreas historicizadas como uma estrutura a ser trabalhada como tal, de maneira mais orgânica (ver observações para o artigo 14\%).

Também nesse artigo $6^{\circ}$, assim como no anterior, é necessário interpretar de maneira fundamentada a "proibição" de alterações: elas são possíveis, mas desde que respeitem a composição do ambiente como estratificado ao longo do tempo.

Artigo $7^{\circ}-$ - monumento é inseparável da história de que é testemunho e do meio em que se situa. Por isso, o deslocamento de todo o monumento ou de parte dele não pode ser tolerado, exceto quando a salvaguarda do monumento o exigir ou quando o justificarem razões de grande interesse nacional ou internacional.

Artigo $8^{\circ}$ - Os elementos de escultura, pintura ou decoração que são parte integrante do monumento não lhes podem ser retirados a não ser que essa medida seja a única capaz de assegurar sua conservação.

Nestes dois artigos está explicitada a inalienabilidade da obra em relação ao contexto em que está inserida: da obra arquitetônica, em relação ao meio em que se situa; das obras escultóricas, pictóricas e ornamentos, em relação ao local onde estão. Exceções feitas a situações extremas, em que não há alternativa. Os problemas de "descontextualização" dos bens culturais e, consequentemente, de dificuldades para sua percepção, haviam sido levantados, ainda no século XVIII, por Quatremère de Quincy, ao colocar-se veemente contra o deslocamento de obras de arte ${ }^{95}$. Brandi também se manifestou de forma enfática sobre o problema: "Donde a remoção de uma obra de arte de seu lugar de origem deverá ser motivada pela única e superior causa da sua conservação"96. No que respeita à arquitetura, vai além, afirmando que "a espacialidade própria ao monumento é coexistente ao espaço ambiente em que foi construído", do que resulta "a absoluta ilegitimidade da decomposição e recomposição de um monumento em lugar diverso daquele onde foi realizado", enfatizando "a degradação do monumento, decomposto e reconstruído em outro lugar, a falso de si mesmo obtido com os seus próprios materiais"; a ação é válida apenas se obra for recomposta no mesmo local: "a legitimidade da decomposição e recomposição ligada apenas à salvaguarda do monumento, quando não for possível assegurar a sua salvação de outro modo, mas sempre e somente em relação ao sítio histórico onde foi realizado"97. Lembre-se de que a Unesco estava às voltas, durante os anos 1960, com o deslocamento dos templos de Abu Simbel, por causa da construção da barragem de Assuã. Daí, talvez, a postura mais contemporizadora do texto da Carta, admitindo exceções também para obras arquitetônicas.

Note-se que, no artigo 8ำ há menção explícita a outras formas de manifestação artística, enfatizando aquilo que Pane já colocara na abertura do Congresso: a visão unitária do problema da preservação como um todo, de critérios gerais para variadas manifestações culturais ${ }^{98}$. Desse modo, a Carta coloca-se contra a tendência que havia, e ainda perdura, de entender a restauração arquitetônica como diversa da restauração dos demais bens culturais. É preconizada uma unidade conceitual e metodológica, mesmo na diversidade
95. O autor, em Lettres à Miranda, de 1796, manifesta-se contra política do Diretório (solidificada em 1796), de espoliação e retirada de obras de arte dos países ocupados pelos exércitos republicanos, principalmente as da Itália, para que fossem transportadas para a França. Para ele, deslocar obras não é propagar, mas dispersar o conhecimento, pois o estudo das obras de arte exige sua reunião no ambiente em que (e para o qual) foram criadas. Apontou os malefícios dessa ação para o estudo das artes, pois obras espalhadas ofereceriam meios incompletos para a educação, julgando que o desmembramento se reverteria contra seus imprudentes autores, uma vez que o museu que se formaria através da "repatriação" não poderia transportar o conjunto em sua inteireza, o que é fundamental para se entender e valorizar as partes que o constituem. Coloca-se assim, veementemente contra a descontextualização das obras: "O verdadeiro museu de Roma, aquele de que falo, se compõe, é verdade, de estátuas, de colossos, de templos, de obeliscos, de colunas triunfais, de termas, de circos, de anfiteatros, de arcos do triunfo, de tumbas, de estuques, de afrescos, de baixos-relevos, de inscrições, de fragmentos de ornamentos, de materiais de construção, de móveis, de utensílios etc., mas ele se compõe não menos dos locais, dos sítios, das montanhas, das pedreiras, das estradas antigas, das posições respectivas das cidades arruinadas, das relações geográficas, das relações de todos os objetos entre si, das lembranças, das tradições locais, dos usos ainda existentes, dos paralelos e aproximações que somente podem ser feitos no próprio local"; cf. Quatremère de Quincy (1989, p. 101-102).

96. Cf. Cesare Brandi (2004, p. 40).

97. Idem, p. 132-134. 
98. Cf. Roberto Pane (1971, p. 2-3).

99. Idem, p. 1 dos meios a serem postos em prática em função da realidade - material, figurativa, estado de conservação, translação no tempo - de cada obra.

\section{Restauração}

Artigo 9ำ- A restauração é uma operação que deve ter caráter excepcional. Tem por objetivo conservar e revelar os valores estéticos e históricos do monumento e fundamenta-se no respeito ao material original e aos documentos autênticos. Termina onde começa a hipótese; no plano das reconstituições conjeturais, todo trabalho complementar reconhecido como indispensável por razões estéticas ou técnicas destacar-se-á da composição arquitetônica e deverá ostentar a marca do nosso tempo. A restauração será sempre precedida e acompanhada de um estudo arqueológico e histórico do monumento.

Existem aí vários enunciados de enorme importância. Note-se o caráter de excepcionalidade conferido às ações de restauro (relembrando ainda a afirmação de Pane, da diferença quantitativa, e não qualitativa, entre conservação e restauro) e os objetivos da ação: conservar e revelar os aspectos históricos e estéticos, respeitando os materiais autênticos que, como visto, é a matéria como transformada pelo tempo.

Caso seja necessário adicionar algum elemento, o acréscimo deverá ser feito com linguagem contemporânea. Aqui está enunciado o princípio da distinguibilidade da ação contemporânea: ou seja, qualquer nova inserção deverá colocar-se como novo estrato, que não induza o observador ao engano de confundi-la com a obra como estratificada antes da intervenção, não propondo o tempo como reversível e devendo documentar a si mesma. Isso já aparecia de forma explícita nas formulações de Boito, em que acréscimos e renovações, se necessários, deveriam ter caráter diverso do original, mas de modo a não destoar do conjunto; completamentos de partes deterioradas ou faltantes deveriam, mesmo seguindo a forma primitiva, ser de material diverso ou ter incisa a data de sua restauração ou, ainda, no caso das restaurações arqueológicas, ter formas simplificadas. Essas propostas derivam de experiências já realizadas no campo da arqueologia, desde o início do século XIX, e que provêm de formulações feitas ainda no século XVIII, como as de Johann Joachim Winckelmann. Esses temas foram retomados por Giovannoni, que teve papel relevante na redação da Carta de Atenas de 1931 e da Carta Italiana de restauro de 1931-1932. Mas a discussão daquele período pautava-se numa visão da integração através de "neutros" - em estilo similar ao original, mas usando formas simplificadas -, expressões formais sem "personalidade decorativa". Esse modo de lidar com os aspectos figurativos na restauração havia mostrado seus limites em razão das destruições da Segunda Guerra Mundial, e passaram por releituras daquele período, dados os novos problemas que a situação colocava ${ }^{99}$. Na Carta de Veneza, a questão muda de escala em relação à de Atenas. Tomam-se por base os princípios do "restauro filológico" de Boito e Giovannoni, dando um passo além, ao buscar-se expressividade mais adequada, a partir de uma linguagem marcadamente contemporânea, associada a teorias estéticas. 
Desse modo, restaurar não é voltar ao estado primitivo ou a um estado anterior qualquer; se forem necessários acréscimos, devem inserir-se de modo a mostrar ser uma intervenção da época em que foram feitos, não se confundindo com o texto existente da obra. Lemaire comenta, como citado anteriormente, que esse enunciado foi muito abusado; na prática, a ação contemporânea acabou por sobrepujar o monumento histórico, desconsiderando os limites impostos pelos artigos $12^{\circ}$ e $13^{\circ}$.

Artigo $10^{\circ}-$ Quando as técnicas tradicionais se revelarem inadequadas, a consolidação do monumento pode ser assegurada com o emprego de todas as técnicas modernas de conservação e construção cuja eficácia tenha sido demonstrada por dados científicos e comprovada pela experiência.

Aqui o enunciado foi colocado com maior cautela do que na Carta de Atenas, em que transparecia maior fé nas novas técnicas ("aprovam o emprego adequado de todos os recursos da técnica moderna e, especialmente, do cimento armado"I, que acabaram por gerar, depois, seríssimos problemas. Nos anos 1930, não se tinha o controle adequado dos materiais, nem conhecimentos suficientes sobre seu comportamento ao longo do tempo. Isso ocorreu com muitas intervenções com concreto armado (a começar pelos trabalhos de Balanos no Partenon, discutidos e elogiados na conferência de Atenas), por não haver um recobrimento suficiente das armações metálicas e acabar por agravar os danos; e, posteriormente, com tintas à base de polímeros sobre argamassas à base de cal, por exemplo. Nota-se uma postura muito mais prudente em Veneza, ao exigir-se eficácia do comportamento dos materiais, comprovada através da experiência. Esse é um enunciado que preconiza a compatibilidade de técnicas e materiais, algo à primeira vista óbvio, mas que vem sendo reiteradamente desrespeitado na prática.

A esse respeito, Brandi já se manifestara de maneira enfática, em texto sobre a restauração da pintura antiga, publicado originalmente em 1958:

Instituto é terminantemente contrário ao uso de novos materiais sintéticos ou mesmo de aglomerados, prensados e assim por diante, de que existe uma experiência de apenas poucos quinquênios. Antes de substituir um material de longo uso de que se tenha a experiência de séculos e de que, por isso, se conheçam bem tanto os defeitos quanto as qualidades, deve-se ter certa prudência que não será jamais excessiva ${ }^{100}$.

Note-se que, na Carta de Veneza, não aparece de maneira explícita outro preceito considerado basilar para a restauração, a "reversibilidade"101 - que juntamente com a distinguibilidade da ação contemporânea, a mínima intervenção e a compatibilidade de técnicas e materiais - é um dos pilares da restauração, a serem respeitados, sempre, conjuntamente. Talvez pelo fato de, na restauração arquitetônica, ser muito difícil de ser alcançada a literal reversibilidade - como em tratamentos, feitos com aquarela, de lacunas em afrescos -, a exemplo de determinadas consolidações estruturais. No entanto, esse tema tem sido tratado, mais recentemente e de maneira mais precisa, como "retrabalhabilidade", algo
100. Cf. Cesare Brandi (2004, p. 147-148).

101. A "reversibilidade" ou "retrabalhabilidade" é um dos princípios basilares da restauração, como passa a ser enunciada em meados do século passado, sendo recorrente nas propostas de Brandi e Philippot, por exemplo. Albert e Paul Philippot (1959, p. 11) afirmaram: o restauro "permanece essencialmente uma hipótese crítica, uma proposta sempre modificável, sem alteração do original, até quando uma crítica mais bem esclarecida julgar necessário". Há um exemplo pioneiro, e raro, no século XVII, em que Carlo Maratta, segundo indicações de Giovan Pietro Bellori, ao restaurar os afrescos de Rafael no palácio da Farnesina, em Roma, em 1693, adotou postura verdadeiramente conservativa (apesar de intervenções mais incisivas que ele próprio fizera em afrescos do mesmo Rafael no Vaticano): estabeleceu processo multidisciplinar, que englobou obras de consolidação, limpeza e tratamento de lacunas. Deliberadamente, procedeu de modo (de fato) reversível com as lacunas, ao fazer completamentos com lápis e pastel; cf. Jukka Ilmari Jokilehto (1999, p. 54). 
102. Cf. Cesare Brandi (2004, p. 146).

103. Aí está um dos pontos de maior conflito entre duas das vertentes atuais: a do restauro crítico-conservativo (herdeiro direto do restauro crítico) e a da conservação integral. Por enfatizar que juízos historiográficos são sempre relativos, pois não existe um juízo infalível e atemporalmente válido (como acreditava o positivismo oitocentista), a conservação integral entende a obra como um documento histórico a ser respeitado em todos os seus estratos. A remoção de adições não é proponível. Já na vertente crítico-conservativa, o juízo histórico-crítico tem de ser baseado no pensamento crítico e científico da própria época, para que seja juízo, e não, opinião arbitrária, tendo-se plena consciência de que é leitura de um presente histórico, que não é válido para todo o sempre e, portanto, sua pertinência é relativa. Daí toda a prudência das formulações, conferindo excepcionalidade ao ato de restauro e pautando-se no princípio da mínima intervenção. que, mais uma vez, iá havia sido enunciado por Brandi, na Teoria da Restauração, em que afirma ser necessário

considerar que o escopo essencial da restauração não é apenas assegurar a subsistência da obra no presente, mas também assegurar a transmissão no futuro; dado que ninguém poderá jamais estar seguro de que a obra não terá necessidade de outras intervenções no futuro, mesmo que simplesmente conservativas, deve-se facilitar e não impedir as eventuais intervenções sucessivas ${ }^{102}$.

Na Carta de Veneza, isso não está explicitado de maneira tão clara; mas a prudência preconizada, sim.

Artigo 1 1 - As contribuições válidas de todas as épocas para a edificação do monumento devem ser respeitadas, visto que a unidade de estilo não é a finalidade a alcançar no curso de uma restauração, a exibição de uma etapa subjacente só se justifica em circunstâncias excepcionais e quando o que se elimina é de pouco interesse e o material que é revelado é de grande valor histórico, arqueológico, ou estético, e seu estado de conservação é considerado satisfatório. O julgamento do valor dos elementos em causa e a decisão quanto ao que pode ser eliminado não podem depender somente do autor do projeto.

A Carta de Veneza reitera proposições que se colocavam, desde o final do século XIX, contra a unidade de estilo e preconizavam o respeito pelas várias estratificações. Esses preceitos já estavam explicitados nas resoluções de 1883, do IV Congresso de Engenheiros e Arquitetos italianos, baseadas em propostas de Boito, adotadas pelo Ministério da Educação do país. Em âmbito austríaco, aparece nas proposições de Riegl. No contexto internacional, isso está enunciado na Carta de Atenas ("a conferência recomenda que se respeite a obra histórica e artística do passado, sem prejudicar o estilo de nenhuma época").

O artigo trała também da remoção de adições - tema delicadíssimo, explorado, na época, por vários autores, através da dialética entre as instâncias estética e histórica. A remoção é justificável apenas em casos excepcionais e, para tanto, é necessário trabalhar através de juízo de valor ${ }^{103}$. Não se trata da opinião de um indivíduo, mas de um efetivo juízo (nesse caso de ascendência Kantiana, como se pode ver nas formulações de Brandi), calcado no pensamento crítico e científico de uma época, juízo esse que não pode ser dependente de uma única pessoa e deve advir de equipe multidisciplinar. Esse é um tema que, apesar do alargamento daquilo que passou a ser considerado bem cultural, continua em pauta; mas, como existe o interesse por documentos cada vez mais variados, a ação se torna mais "conservativa". Aquilo que é passível de remoção é, hoje, mais restrito do que nos anos 1960. Isso, entretanto, não invalida o enunciado: pelo contrário, mostra que o trabalho multidisciplinar deve operar com os meios e com os critérios de seu próprio tempo.

Artigo $12^{\circ}-$ Os elementos destinados a substituir as partes faltantes devem integrar-se harmoniosamente ao conjunto, distinguindo-se, todavia, das partes originais a fim de que a restauração não falsifique o documento de arte e de história. 
Artigo $13^{\circ}$ - Os acréscimos só poderão ser tolerados na medida em que respeitarem todas as partes interessantes do edifício, seu esquema tradicional, o equilíbrio de sua composição e suas relações com o meio ambiente.

Esses dois artigos circunscrevem de maneira mais clara os limites da intervenção contemporânea. Retomam a importância da relação entre as instâncias estética e histórica, e recomendam respeito absoluto pelo edifício e pelo ambiente em que está inserido. Os artigos estão em acordo com o $2^{\circ}$ axioma da teoria de Brandi, de que "a restauração deve visar ao restabelecimento da unidade potencial da obra de arte, desde que isso seja possível sem cometer um falso artístico ou um falso histórico, e sem cancelar nenhum traço da passagem da obra de arte no tempo"104, e com as propostas do restauro crítico. De nenhum modo deve trabalhar-se por analogia (falso histórico), e a configuração da obra e sua translação ao longo do tempo deve ser respeitada. Em relação a como alcançar esse equilíbrio, Brandi aconselha desenvolver as sugestões implícitas nos próprios fragmentos e, em casos de substituição de edifícios que vierem a ruir num ambiente a ser preservado, a linguagem deve ser trabalhada "com base nos dados espaciais, e não, naqueles formais do monumento que desapareceu" ${ }^{\prime 05}$. $\bigcirc$ artigo preconiza uma identidade de efeito, e não imitação da forma, através de uma abstração volumétrica extraída da leitura da obra, ou das obras circunstantes, sem recair em imitação, em competição ou falsificação. Carbonara, para não incorrer em imitações, aconselha a analisar a estrutura formal da obra, utilizando instrumentos e linguagem pessoais e contemporâneos, baseados na "forma formante" e não na imitação da "forma formada" (interpretando propostas de Luigi Pareyson) ${ }^{106}$, sem retomar de modo literal as formas desaparecidas. Esse processo só pode advir de acurada análise formal da obra e do ambiente em que está inserida, algo que é apoiado em teorias artísticas e no uso da criatividade ${ }^{107}$.

\section{Sítios Monumentais}

Artigo $14^{\circ}$ - Os sítios monumentais devem ser objeto de cuidados especiais que visem a salvaguardar sua integridade e assegurar seu saneamento, sua manutenção e valorização. Os trabalhos de conservação e restauração que neles se efetuarem devem inspirar-se nos princípios enunciados nos artigos precedentes.

Esse artigo possui um enunciado que remete o tratamento de conjuntos arquitetônicos aos mesmos princípios de conservação e restauro dos monumentos singulares, ou seja, conclamando à unidade conceitual e metodológica, cujas premissas são de natureza cultural, com ênfase nas instâncias estética e histórica. Tal formulação tem, também, o intuito de que o tratamento do problema não seja desviado do campo cultural por conta de questões econômicas, utilitárias etc. $\bigcirc$ tema, por aparecer de maneira tão concisa - o próprio Pane reconhecia que deveria ser aprofundado 108 - e por adquirir importância cada vez maior ao longo dos anos, recebendo grande atenção por parte do Conselho da Europa, através da Declaração e da Carta de Amsterdã (de 1975, que trabalham com questões de conservação integrada), será retomado pelo próprio lcomos na Carta de
104. Cf. Cesare Brandi (2004, p. 33).

105. Idem, p. 47.

106. Cf. Giovanni Carbonara (1997, p. 414-415).

107. Para referências bibliográficas acerca da relação entre restauro e teorias estéticas e artísticas, ver nota 85

108. Cf. Roberto Pane (1976). 
Washington (de 1987), documento integrativo (e não substitutivo) em relação à Carta de Veneza.

\section{Escavações}

Artigo $15^{\circ}$ - Os trabalhos de escavação devem ser executados em conformidade com padrões científicos e com a "Recomendação Definidora dos Princípios Internacionais a serem aplicados em Matéria de Escavações Arqueológicas", adotada pela Unesco em 1956.

Devem ser asseguradas as manutenções das ruínas e as medidas necessárias à conservação e proteção permanente dos elementos arquitetônicos e dos objetos descobertos. Além disso, devem ser tomadas todas as iniciativas para facilitar a compreensão do monumento trazido à luz sem jamais deturpar seu significado.

Todo trabalho de reconstrução deverá, portanto, deve ser excluído a priori, admitindo-se apenas a anastilose, ou seja, a recomposição de partes existentes, mas desmembradas. Os elementos de integração deverão ser sempre reconhecíveis e reduzir-se ao mínimo necessário para assegurar as condições de conservação do monumento e restabelecer a continuidade de suas formas.

Nesse artigo, a Carta remete o tratamento da questão a outro documento, da Unesco; posteriormente, o lcomos enfrentaria o tema na carta para gestão do patrimônio arqueológico (1990). No artigo, retomam-se as colocações da Carta de Atenas: "Quando se trata de ruínas, uma conservação escrupulosa se impõe, com a recolocação em seus lugares dos elementos originais encontrados (anastilose), cada vez que o caso o permita; os materiais novos necessários a esse trabalho deverão ser sempre reconhecíveis". Nesse artigo, são reiterados os princípios da distinguibilidade e da mínima intervenção, mencionados anteriormente na Carta de Veneza, sempre lembrando que esses critérios, em especial para o campo da arqueologia, provêm de uma longa linhagem, remontando às discussões do século XVIII, em especial a partir das formulações de Winckelmann.

\section{Documentação e Publicações}

Artigo $16^{\circ}$ - Os trabalhos de conservação, de restauração e de escavação serão sempre acompanhados pela elaboração de uma documentação precisa sob a forma de relatórios analíticos e críticos, ilustrados com desenhos e fotografias. Todas as fases dos trabalhos de desobstrução, consolidação recomposição e integração, bem como os elementos técnicos e formais identificados ao longo dos trabalhos serão ali consignados. Essa documentação será depositada nos arquivos de um órgão público e posta à disposição dos pesquisadores; recomenda-se sua publicação.

Essa recomendação, em aparência evidente, deveria ser uma prática consolidada há muito tempo e parte integrante de intervenções. Infelizmente isso não se concretiza como certamente deve. Entretanto são propostas que já compareciam em textos de Viollet-le-Duc, em meados do século XIX, e que são reiteradas por Camillo Boito e pela Carta de Atenas (item VII, c), sendo essenciais para a elaboração de um projeto fundamentado e para o controle da obra, e, ainda, para a divulgação e apreciação crítica dos resultados obtidos. 
A Carta de Veneza permanece um texto basilar. É um documento sintético, cujas indicações - desde que devidamente reinterpretadas para a realidade contemporânea, levando em conta a ampliação daquilo que passou a ser considerado bem cultural - continuam válidas para enfrentar as questões ligadas à preservação de monumentos históricos. Deve ser lida, sempre, em sua inteireza, considerando sua base teórica - e também suas limitações -, analisando-a de maneira não-restritiva, de modo a alargar seu conteúdo semântico e dilatar sua compreensão de maneira fundamentada.

\section{REFERÊNCIAS}

BASILE, Giuseppe. A atualidade da Teoria da Restauração de Cesare Brandi: alguns exemplos. Pós, São Paulo, n. 16, p. 143-146, 2004.

BELLINI, Amedeo. Tecniche della conservazione. Milano: Franco Angeli, 2003.

BERGEON LANGLE, Segolène. Cesare Brandi et la France: l'Institut Central de Restauration de Rome et le Louvre. In: BASILE, Giuseppe (Org.). Cesare Brandi oggi. Prime ricognizioni. Saonara: Il Prato, 2008. p. 170-182.

BOIRET, Yves. Restauration et utilisation. Les Monuments bistoriques de France, Paris, numéro hors-série, p. 63-72, 1977.

BOITO, Camillo. Questioni pratiche delle belle arti. Restauri, concorsi, legislazione, professione, insegnamento. Milano: Hoepli, 1893.

Os restauradores. Cotia: Ateliê, 2002.

BONELLI, Renato. Architettura e restauro. Venezia: Neri Pozza, 1959.

Il Restauro Architettonico. In: Enciclopedia Universale dell'Arte. Novara: Istituto Geografico de Agostini, 1963.

Scritti sul restauro e sulla critica architettonica. Roma: Bonsignori, 1995.

BRANDI, Cesare. Il fondamento teorico del restauro. Bollettino dell'Istituto Centrale del Restauro, Roma, n. 1, p. 5-12, 1950.

L'Institut central pour la restauration d'œuvres d'art a Rome. Gazette des beaux-arts, Paris, v. 43, p. 42-52, 1954.

Cosa debba intendersi per restauro preventivo. Bollettino dell'Istituto Centrale del Restauro, Roma, n. 27-28, p. 87-92, 1956.

Concetto del restauro. In: Enciclopedia Universale dell'Arte. Novara: Istituto Geografico de Agostini, 1963.

Le due vie. Bari: Laterza, 1966.

Teoria da restauração. Cotia: Ateliê, 2004.

CARBONARA, Giovanni. La reintegrazione dell'immagine. Problemi di restauro dei monumenti. Roma: Bulzoni, 1976. 

$57-60$.

I trent'anni di una buona carta del restauro. Restauro, Napoli, 1995, v. 24, n. 131-132, p.

Avvicinamento al restauro. Teoria, storia, monumenti. Napoli: Liguori, 1997

Brandi e a restauração arquitetônica hoje. Desígnio, São Paulo, n. 6, p. 35-47, 2006.

CARTA DE ATENAS. Disponível em: <http://portal.iphan.gov.br/portal/baixaFcdAnexo. do? id=232> . Acesso em: 4 mar. 2010.

CARTA DE VENEZA. Disponível em: <http://portal.iphan.gov.br/portal/baixaFcdAnexo. do?id=236 $>$. Acesso em: 4 mar. 2010.

CHASTEL, André. Restauration et avenir du patrimoine. Les Monuments bistoriques de France. Paris, numéro hors-série, p. 102-108, 1977.

CHATELAIN, Jean. Préface au colloque. Les Monuments bistoriques de France, Paris, numéro hors-série, p. 8, 1977.

CHOAY, Françoise. Sept propositions sur le concept d'authenticité et son usage dans les pratiques du patrimoine historique”. In: UNESCO. Nara Conference on Authenticity. Paris: Unesco, 1995, p. 101-120.

A alegoria do patrimônio. São Paulo: UNESP, 2001

CLOQUET, Louis. La restauration des monuments anciens. Revue de l'art chrétien, Bruxelles, p. 498-503, 1901.

CONGRESSO DEGLI INGEGNERI ED ARCHITETTI ITALIANI, 4. genn. 1883, Roma. Atas. Roma: Centernari, 1884 .

CONTI, Alessandro. Sul restauro. Tornino: Einaudi, 1988.

CORDARO, Michele. Sull'inutilità di una nuova carta del restauro. Restauro É città, Veneza, $\mathrm{n}$. 11-12, p. 97-101, 1989.

CRESPI, Luigi. Monumenti vivi o morti. In: ICOMOS. Il monumento per l'uomo. Atti del II Congresso Internazionale del Restauro. Venezia 25-31 maggio 1964. Padova: Icomos; Marsilio, 1971. p. 136-139

D'ANGELO, Paolo. Cesare Brandi. Critica d'arte e filosofia. Macerata: Quod Libet, 2006.

DE ROUX, Emmanuel. Patrimoine industriel. Paris: Scala, 2000.

DETRY, Nicolas; PRUNET, Pierre. Architecture et restauration. Sens et évolution d'une recherche. Paris: De la Passion, 2000.

DEZZI-BARDESCHI, Marco. Restauro: due punti e da capo. Milano: Franco Angeli, 2004.

FERREIRA, António Gomes. Dicionário de Latim-Português. Porto: Porto Editora, 1991.

GAZZOLA, Piero; PANE, Roberto. Proposte per uma carta internazionale del restauro. In: ICOMOS. Il monumento per l'uomo. Atti del II Congresso Internazionale del Restauro. Venezia 25-31 maggio 1964. Padova: Icomos; Marsilio, 1971. p. 14-19.

HERNÁNDEZ MARTÍNEZ, Ascensión. La clonación arquitectónica. Madrid: Siruela, 2007.

HORLER, Miklós. La Charte de Venise et la restauration des monuments historiques em Hongrie. Icomos Bulletin, Paris, n. 1, p. 52-125, 1971. Disponível em: <http://www.international.icomos. org/publications/bulletin1971.htm>.

ICCROM. ICCROM Newsletter, Roma, n. 35, Oct. 2009. 
ICOMOS. Il monumento per l'uomo. Atti del II Congresso Internazionale del Restauro. Venezia 25-31 maggio 1964. Padova: Icomos; Marsilio, 1971.

ICOMOS. The Venice Charter 1964-2004-2044? Paris: Icomos, 2004.

ICOMOS-Austrália. Carta de Burra (1980). Disponível em: <http://portal.iphan.gov.br/portal/ baixaFcdAnexo.do?id=251>. Acesso em: 14 jan. 2010.

ICOMOS-Wallonie. La Charte de Venise, 30 ans plus tard. Namur: Icomos-Wallonie, 1994.

INSTITUTO ANTÔNIO HOUAISS. Dicionário eletrônico Houaiss da língua portuguesa. Rio de Janeiro: Objetiva, 2007.

JOKILEHTO, Jukka Ilmari. A History of Architectural Conservation. Oxford: Butterworth-Heinemann, 1999.

KEMP, Wolfgang. Alois Riegl. In: DILLY, H. (Org.). Altmeister moderner Kunstgeschichte. Berlim: Dietrich Reimer, 1990, p. 37-60.

KÜHL, Beatriz Mugayar. Preservação do Patrimônio Arquitetônico da Industrialização. Cotia: Ateliê, 2009.

LEAL, Fernando Machado. Restauração e conservação de monumentos brasileiros: subsídios para o seu estudo. Recife: UFPE, 1977.

LE GOFF, Jacques. História e memória. Campinas: Editora Unicamp, 2003.

LEMAIRE, Raymond. Rapport général. In: ICOMOS. Il monumento per l'uomo. Atti del II Congresso Internazionale del Restauro. Venezia 25-31 maggio 1964. Padova: Icomos; Marsilio, 1971. p. 147-152.

Icomos: un regard en arrière, un coup d'œil en avant. Liège: Commission Royale de Monuments et Sites, 1999.

LIRA, Flaviana Barreto. Patrimônio cultural e autenticidade: montagem de um sistema de indicadores para o monitoramento. 2009. Tese (Doutorado em Planejamento Urbano e Regional) - Programa de Pós-Graduação em Desenvolvimento Urbano (MDU)-Universidade Federal de Pernambuco, Recife, 2009.

MARAMOTTI POLITI, Anna Lucia. Passato, memoria, futuro. La conservazione dell'architettura. Milano: Guerini, 1996.

MARCONI, Paolo. Materia e significato. Roma: Laterza, 1999.

Il restauro e l'architetto. Venezia: Marsilio, 1993.

MAYUMI, Lia. Taipa, canela-preta e concreto. Estudo sobre o restauro de casas bandeiristas. São Paulo: Romano Guerra, 2008.

MIARELLI MARIANI, Gaetano. I restauri di Pierre Prunet: un pretesto per parlare di architettura. Palladio, Roma, n. 27, p. 65-92, 2000.

OBERHAIDACHER, Jörg. Riegls Idee. Wiener Jabrbuch für Kunstgeschichte, Wien, v. 28, p. 199-218, 1985.

OLIN, Margaret. Forms of respect: Alois Riegl's concept of attentiveness. The Art Bulletin, London, v. 71, n. 2, p. 285-299, 1989.

OFFICE INTERNATIONAL DES MUSÉES. La Conservation des monuments d'art et d'histoire. Paris: Office International des Musées, 1933.

PANE, Roberto. Architettura e arti figurative. Venezia: Pozza, 1948. 
Attualità dell'ambiente antico. Firenze: La Nuova Italia, 1967.

Conférence introductive. ICOMOS. Il monumento per l'uomo. Atti del II Congresso Internazionale del Restauro. Venezia 25-31 maggio 1964. Padova: Icomos; Marsilio, 1971. p. 1-12.

Il convegno di Parigi sulla Carta di Venezia: interventi e note critiche di Roberto Pane. Restauro, Napoli, n. 27, p. 105-108, 1976.

Attualità e dialettica del restauro. Chieti: Solfanelli, 1987.

PARENT, Michel. Problèmes de la restauration avec l'environnement sociologique et culturel. Les Monuments bistoriques de France, Paris, numéro hors-série, p. 10-19, 1977.

PHILIPPOT, Albert; PHILIPPOT, Paul. Le Problème de l'intégration des lacunes dans la restauration des peintures. Bulletin de l'Institut Royale du Patrimoine Artistique, Bruxelles, v. 2, p. 5-19, 1959.

Réflexions sur quelques problèmes esthétiques et techniques de la retouche. Bulletin de l'Institut Royale du Patrimoine Artistique, Bruxelles, v. 3, p. 163-172, 1960.

PHILIPPOT, Paul. Historic Preservation: Philosophy, Criteria, Guidelines. In: Preservation and Conservation: Principles and Practices. Washington: The Preservation Press, 1976, p. 367-382.

La Notion de patine et le nettoyage des peintures. Bulletin de l'Institut Royale du Patrimoine Artistique, Bruxelles, v. 9, p. 138-143, 1966.

PONSOT, Patrick. Leçons américaines. La Tribune de l'Art, 2006. Disponível em: <www. latribunedelart.com/Debats/Debats_2006/Lecons_americaines>. Acsso em: 4 mar. 2010.

QUATREMÈRE DE QUINCY. Lettres à Miranda sur le déplacement des monuments de l'art de l'Italie (1796). Paris: Macula, 1989.

SAINTENOY, Paul. Le Congrès international pour la protection des ouvres d'art et des monuments tenu à Paris en 1889. L'Emulation, Bruxelles, n. 10, 1889. coln. 149.

SCARROCCHIA, Sandro (Org.). Alois Riegl: teoria e prassi della conservazione dei monumenti. Bologna: Accademia Clementina di Bologna, 1995.

SEVERINO, Emanuele. Tecnica e architettura. Milano: Raffaello Cortina, 2003.

SIRINELLI, Jean. La préhistoire de l'Unesco. In: FONTAINE, Jacques (Org.). Bicentenaire de l'Institut de France. Actes des Colloques. Paris: Fayard, 1995. p. 490-493.

TORSELlO, B. Paolo (Org.). Che cos'è il restauro. Nove studiosi a confronto. Venezia: Marsilio, 2005.

UNESCO. Nara conference on authenticity. Paris: Unesco, 1995.

The Operational Guidelines for the Implementation of the World Heritage Convention (2008). Disponível em: <http://whc.unesco.org/en/guidelines/>. Acesso em: 18 fev. 2010.

VAROLI-PIAZZA, Rosalia. Brandi e l'ICCROM: una stretta collaborazione per la conservazione del patrimonio culturale internazionale. In: BON VALSASSINA, Caterina (Org.). Omaggio a Cesare Brandi nel centenario della sua nascita. Firenze: Edifir, 2008. p. 83-90.

Artigo apresentado em 8/2010. Aprovado em 10/2010. 